\title{
EM TEMPO DE COPA DO MUNDO, OS JOGOS DOS POVOS INDÍGENAS EM CUIABÁ
}

ALOIR PACINI ${ }^{1}$

UFMT

RESUMO: $O$ texto traz alguns elementos que levam a compreender a estrutura dual nas modalidades de jogos presentes nas Olimpíadas Indígenas de Cuiabá em 2013, especialmente os jogos de futebol. O "futebol de cabeça", tradicional entre algumas etnias matogrossenses, mostra que o futebol inglês não é tão estranho assim para os indígenas que assistiram a Copa do Mundo de futebol com grande interesse em 2014. O autor observou que a escolha dos locais dos jogos possuía interesses lúdicos e econômicos, por isso talvez a definição das etnias que jogaram seguia mais o critério dos não-indígenas do que os oficialmente propalados interesses indígenas. Parece ser esta a causa pela qual os Chiquitanos, enquanto etnia indígena em confronto declarado com o Governo do Estado de Mato Grosso, não tiveram espaço nos Jogos Indígenas de Cuiabá. Outro aspecto que torna isso visível é o fato de que somente algumas etnias possuíam espaço adequado para a venda dos seus artefatos. Apesar destes e de outros contratempos, os nativos Pataxós na Terra de Santa cruz souberam conectar-se com seus parentes pelas pinturas corporais, na venda dos seus artefatos e com os campeões do futebol alemães.

PALAVRAS-CHAVE: Jogos Indígenas; Futebol; Copa do Mundo.

ABSTRACT: The text brings some insights that lead to understanding the dual structure in the game rules of the Indigenous Olympics Cuiabá in 2013, especially football games. The "head football", traditional among some indigenous in Mato Grosso shows that English football is not so strange to the Indians who watched on television the World Cup football with great interest in 2014. The author noted that the choice of places of entertainment and games had economic interests, so perhaps the definition of ethnic groups who have played more followed the criterion of non-indigenous than the officially publicized indigenous interests. This seems to be the cause for which the Chiquitanos while indigenous ethnic group in confrontation declared with the State of Mato Grosso, did not have space in the Indigenous Games Cuiabá. Another aspect that makes it visible is the fact that only some ethnic groups had adequate space for the sale of its artifacts. Despite these and other setbacks, the natives Pataxós in the Land of Santa Cruz knew how to connect with their relatives by body painting, in selling their artifacts and with the German football champions.

KEYWORDS: Indigenous Games; Football; World Cup.

\footnotetext{
${ }^{1}$ Professor do Departamento de Antropologia e do PPGAS da UFMT, Doutor pelo PPGAS da UFRGS em 2012, com a tese Identidade étnica e território chiquitano na fronteira (Brasil-Bolívia). E-mail: aloirpacini@gmail.com.
}

Espaço Ameríndio, Porto Alegre, v. 8, n. 2, p. 168-204, jul./dez. 2014. 

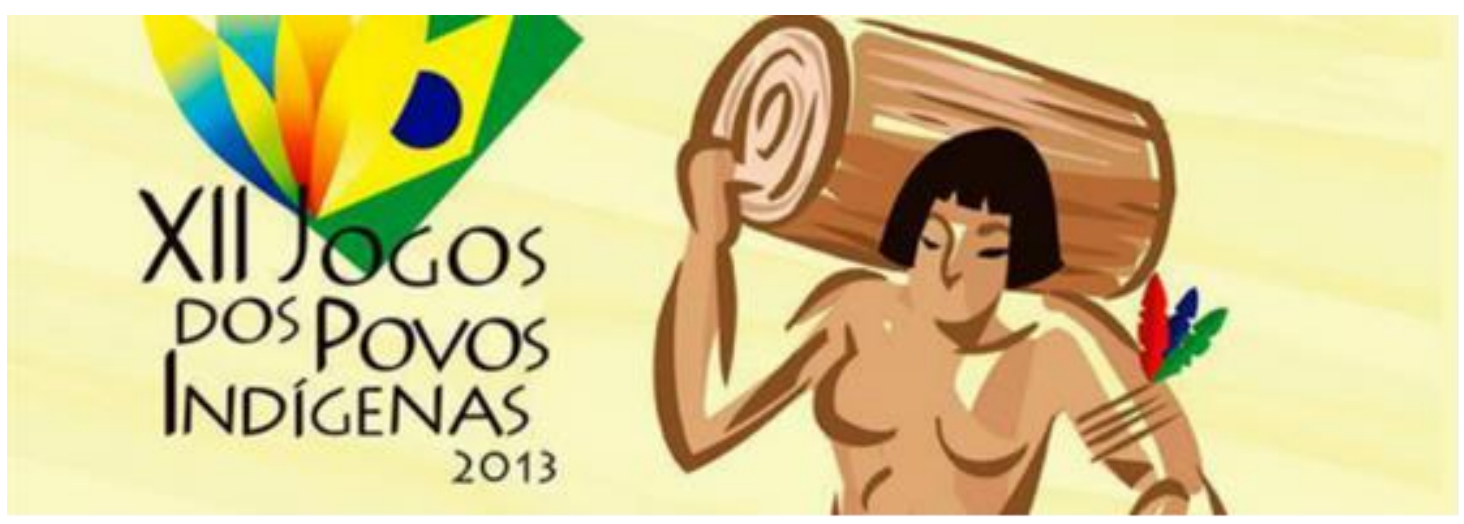

Imagem 1: Logotipo dos Jogos em Cuiabá com a indicação da corrida de torra tradicional entre algumas etnias do Mato Grosso, associando a braçadeira às cores da bandeira nacional ${ }^{2}$.

Tratado por muitos como um evento do Ministério do Esporte ${ }^{3}$, os Jogos Indígenas dizem respeito a um processo cultural e social que é usado politicamente e que desejamos abordar neste artigo. A XII edição dos Jogos dos Povos Indígenas aconteceu entre os dias 8 e 16 de novembro de 2013, no Jardim Botânico de Cuiabá, Mato Grosso. Os meios de comunicação ${ }^{4}$ divulgaram amplamente e os anúncios "em grande estilo" possuíam um apelo claro de venda de um produto valioso, mas exótico. Por isso, em geral, eram colocados como chamariz de público o estereótipo do índio que costumamos encontrar nos meios de comunicação como a imagem dos xinguanos no estilo da imagem 2 .

\footnotetext{
${ }^{2}$ Da mesma forma que a edição XII dos Jogos, o logotipo da edição XI dos Jogos possui cores semelhantes, porém distintivo na indicação do arco e flecha e no contexto estilizado num ambiente rural. A XI edição dos Jogos dos Povos Indígenas foi realizada em Porto Nacional - TO, na Ilha de Porto Real, nos dias 05 a 12 de novembro de 2011 e contou com a participação de 30 etnias indígenas, segundo os organizadores.

${ }^{3} \mathrm{O}$ evento, organizado pelo ITC (Comitê Intertribal Memória e Ciência Indígena) estava previsto inicialmente entre 11 a 19 de outubro de 2013 e foi adiado para a presente data. Foi patrocinado pelo Ministério do Esporte com apoio dos Ministérios do Desenvolvimento Agrário, da Cultura, da Saúde, da Educação, do Turismo, da Justiça e da Secretaria de Políticas de Promoção da Igualdade Social (SEPPIR), Infraero, Governo de Mato Grosso e Prefeitura de Cuiabá, com o fim de promover as culturas ameríndias e suas modalidades esportivas tradicionais, uma articulação liderada Marcos Terena.

${ }^{4}$ Websites como Portal Brasil, Facebook, YouTube, UOL Notícias, TV UOL, lancenet, globotv, entre outros, divulgaram para o mundo todo e deram visibilidade a este evento, cumprindo um dos objetivos dos Jogos Indígenas.
}

Espaço Ameríndio, Porto Alegre, v. 8, n. 2, p. 168-204, jul./dez. 2014. 
ALOIR PACINI - Em tempo de Copa do Mundo, os jogos dos povos indígenas em Cuiabá

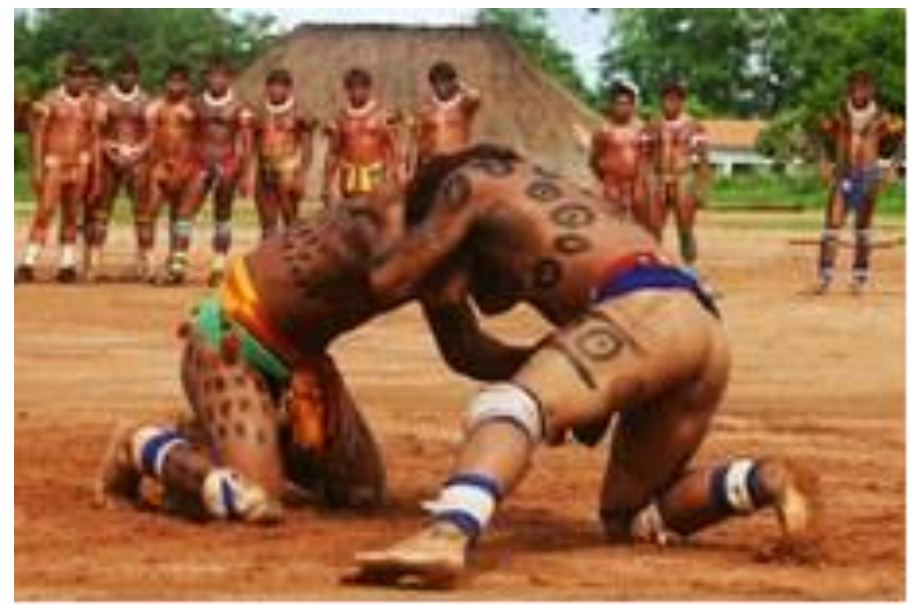

Imagem 2: Huka huka, esporte tradicional dos xinguanos no contexto de aldeia trazidos pela mídia para a cidade virtualmente pois não era uma das modalidades das competições porém chama a atenção do público para um mundo que não conhece a fundo, porém admira, nossas lutas ancestrais (PORTAL BRASIL, 2013).

Segundo os anúncios, a XII edição dos Jogos Indígenas desejava juntar cerca de 1600 índios de 48 etnias nacionais, além de 16 representações indígenas internacionais, o que é bombástico e corresponde a uma mania de grandeza própria destas terras de Santa Cruz. O público em geral deseja ver este indígena exotizado, imagem reforçada pelos meios de comunicação, por isso se decepcionava por vezes com o indígena que não correspondia a estas expectativas.

Um evento desta grandeza exige uma grande estrutura. As instalações necessárias eram responsabilidade do Governo do Estado de Mato Grosso que administraria os recursos do Ministério do Esporte. Foi anunciado um mês antes do início do evento que a limpeza do terreno já estava concluída, porém, no dia da chegada dos indígenas à cidade, ainda os tratores estavam no local revolvendo a terra. E as áreas da Aldeia Okara que iriam receber a arena dos Jogos, as ocas da Sabedoria (Digital e da Literatura), o alojamento das delegações, a feira de artesanato, o restaurante e os banheiros já tinham seus locais demarcados.

A instalação da rede elétrica e a infraestrutura do evento seria montada com base na arquitetura indígena a partir de um conceito sustentável, isso com o auxílio do arquiteto José Afonso Botura Porto Carrero, professor do Departamento de Arquitetura e Urbanismo da UFMT, com pesquisas nas tradições arquitetônicas indígenas. $O$ 
ALOIR PACINI - Em tempo de Copa do Mundo, os jogos dos povos indígenas em Cuiabá

secretário de Esportes e Lazer, Ananias Filho, foi ecologicamente correto: "Usaremos matéria-prima reciclada, madeiras certificadas (de manejo) e palhas das palmeiras de buriti e bacuri", pois "É uma oportunidade para mostrar que os índios, além de cultura, têm muita experiência para trocar com a sociedade, principalmente no que se refere à proteção ambiental e alimentação" (PORTAL BRASIL, 2013, n.p.).

Os guerreiros-atletas competiriam em diferentes modalidades tais como: canoagem, arco e flecha, cabo de força (guerra), arremesso de lança, corrida de 100 metros, corrida de tora, natação/travessia do rio Cuiabá, zarabatana, além de lutas corporais como o huka huka e do tão badalado futebol brasileiro (masculino e feminino) ${ }^{5}$, só que neste contexto indígena, bastante velado da propaganda exótica. O interesse pelo futebol, como veremos adiante, provinha mais dos povos indígenas e entrava na pauta sem muito interesse da mídia. A maioria das provas seria disputada na Arena do Jardim Botânico, pois a Arena Pantanal ainda não estava pronta e somente promete inauguração para a Copa do Mundo de Futebol em 2014. Na Arena instalada especialmente no espaço público chamado Sucuri para esta versão XII dos Jogos, próximo ao riacho do Pari com as famosas lendas do Minhocão do Pari que marcam um passado de origem Boe (Bororo) destas plagas ${ }^{6}$. As arquibancadas facilitariam ao público visitante, moradores e estudantes da baixada cuiabana observarem mais de perto a demonstração de diversos esportes tradicionais indígenas, pois o futebol foi extirpado para outros estádios da capital no período da manhã, uma dicotomia que ainda se fez presente de forma sub-liminar entre o exótico indígena que ficou para o espaço da Aldeia Okara e este esporte que não "seria" indígena. Alguns argumentam que nas versões anteriores dos Jogos 0 futebol foi também transferido para estádios, talvez, porque tal espaço é marcado por medidas e demarcações pré-estabelecidas já existentes

\footnotetext{
${ }^{5}$ As partidas de futebol são disputadas por times masculinos e femininos e as regras obedecem aos padrões da Confederação Brasileira de Futebol, com exceção do tempo que é de 25 minutos para cada lado. Alguns nomes das modalidades esportivas nas línguas indígenas dão mistério às competições ou jogos demonstrativos: jikunahati (jogo de bola com a cabeça), hipipi, katulaywa, jawary, tihimore (boliche), rõkran (taco e bola), peikran, kagót, insistró, jãmparty, akô, meomkey, mentabenreré, tumutitekré, háwanri etc.

${ }^{6}$ Para maiores informações ver Vídeo produzido para lançamento dos XII Jogos dos Povos Indígenas postado por Karina Figueredo que faz a narração deste para a publicação (Publicado em 14/08/2013) indicando Ikuia-pá como território tradicional dos Boes (Bororos) que dá uma versão da etimologia do nome da cidade como "rio onde se pesca com arpão" (Cf. FIGUEIREDO, 2014).
}

Espaço Ameríndio, Porto Alegre, v. 8, n. 2, p. 168-204, jul./dez. 2014. 
ALOIR PACINI - Em tempo de Copa do Mundo, os jogos dos povos indígenas em Cuiabá

nos campos de futebol, sendo então desnecessário construí-los no local para abrigar os jogos. Contudo, as medidas dos campos de futebol de cabeça e nas aldeias em geral dão espaço para os jogos chamados comumente de peladas. Fica a pergunta: Por que não poderia ser assim também nos Jogos Indígenas oficiais, já que o objetivo é "celebrar"? Os esportes em geral possuem características racionalistas, com regras pré-estabelecidas e de caráter competitivo e com penalidades para os atletas que não as cumprem, o que os indígenas não aceitam.

Para compreendermos as dinâmicas culturais de forma antropológica e valorizar suas mudanças irei longe buscar uma reflexão pertinente. Émile Durkheim (1914) deu início às discussões a respeito do dualismo da natureza humana e suas condições sociais.

A dualidade acaba se mostrando de forma dramática nos momentos de maior rivalidade de disputas por território ou "mulheres" etc. Nas sociedades humanas em geral acabam por buscar equilíbrios ou a supressão do outro na vitória de um lado. Por isso talvez, enfatiza-se tanto o "celebrar" nos Jogos Indígenas. Durkheim analisa o dualismo e as condições humanas que levam à dualidade mais que à dicotomia e isso poderia ser pensado em relações de guerra e complementaridade como fez Florestan Fernandes (1970) entre os Tupinambás. Estes aspectos possuem lógicas próprias dos indígenas como pude observar entre os Rikbaktsa e Cinta-Largas na região do rio Juruena, mesmo sendo de troncos linguísticos diferentes e disputarem uma mesma área.

Num esforço de síntese, Eduardo Galvão (1973) estabeleceu onze áreas culturais ${ }^{7}$ indígenas existentes no Brasil e se procurava encontrar

\footnotetext{
7 Apesar do reforço no aspecto geográfico que deve ser relativizado, o conceito de área cultural desenvolvido na antropologia norte-americana da primeira metade do século XX pensado como áreas em que se encontram culturas similares que correspondem a conjuntos de elementos ou traços culturais típicos de uma região e atividades humanas relativamente homogêneas que formam um complexo de atividades comuns entre si, ainda é operacional. Nesta herança da antropologia norte-americana, representada por Franz Boas (1858-1942) e Melville Jean Herskovits (1895-1963), a estrutura da cultura seria desenhada a partir do "traço", "complexo", "área" e "padrão". Os estudos comparativos das populações indígenas durante muito tempo se baseou na observação e registro da ocorrência e distribuição de traços culturais, tomados isoladamente ou agrupados em homogeneidades, que formam os denominados complexos culturais, organizados, por sua vez, em suas distintas formas ou padrões. A distribuição de padrões de vida similares numa dada região constituiria uma área cultural. O linguista Matoso Câmara Jr. (1904-1970), na IV Reunião da Associação Brasileira de Antropologia em 1959, assinalou que a classificação "exclusiva" pelo critério linguístico é limitada quanto à detecção das influências de contato ou processos aculturativos e de mudança de cultura, requerendo, portanto essa contribuição da antropologia. Eduardo Galvão, nascido em 19 de abril de 1963, destaca nessa delimitação de área cultural constituída pela articulação entre os espaços geográficos e os espaços sócio-culturais susceptíveis de serem conhecidos, a relação das etnias indígenas entre si e com a sociedade envolvente
}

Espaço Ameríndio, Porto Alegre, v. 8, n. 2, p. 168-204, jul./dez. 2014. 
ALOIR PACINI - Em tempo de Copa do Mundo, os jogos dos povos indígenas em Cuiabá

a estrutura social dual que era tido, na época, como determinada diretamente pelo pensamento de mesma natureza relacionado aos mitos do sol e da lua, isso sem se preocupar no momento com a profundidade histórica e sem levar em consideração de interpenetrações entre as etnias e, evidentemente, das milhões de conexões possíveis com a sociedade envolvente para formar o que é o Brasil atual.

Foi fundamental na época o aparecimento do estudo de Josef Haeckel (1938). Lévi-Strauss tomou a peito um aspecto estrutural que gerava discussão entre os americanistas: a ocorrência de organizações duais na constituição social dos índios sul-americanos. Por isso teve o ensejo de estudar in loco entre os Boes (Bororos) da aldeia Quejara8 do rio Vermelho, afluente do São Lourenço, afluente do Cuiabá, afluente do Paraguai. E este aspecto da dualidade foi valorizado ao extremo, pois logo publicou: "Contribution à l'étude de l'organisation sociale des Indians Bororo" (1936) e "On Dual Organization in South America" (1944).

A área III abrange a margem direita do rio Guaporé e a parte sul da bacia do alto Madeira. Compreende, entre outras, algumas tribos tupi, das quais os Kepikirivát também possuem metades que atuam por ocasião de jogos de bola cerimônias e em outras ocasiões (LéviStrauss, 1948b:375). Aqui, como no caso seguinte, trata-se, evidentemente, de uma dicotomia apenas cerimonial, sem ligação qualquer com a ordem matrimonial (ZERRIES, 1976, p. 106).

Lévi-Strauss não está interessado no contexto social do mito, nem o vê como artifício para explicar o mundo, mas um sistema codificado numa estrutura dialética que pode ser decifrado para compreender a mensagem, por isso cria uma teoria científica que pretende explicar os fenômenos culturais empíricos, contudo está pouco interessado nos

que é "inclusiva", mas também "exclusiva", ou seja, que exclui. É a possibilidade do desenvolvimento de estudos comparativos o que justificava a utilização de critérios arbitrários da geografia ou da língua que pouco interessam em si, mas servem como "sinais diacríticos" aos povos classificados.

${ }^{8}$ Lévi-Strauss realizou uma série de expedições pelo Mato Grosso entre 1935 e 1940 e pesquisou entre os Kadiwéus, Boes e Nambikwaras, mas foi entre os Boes que encontrou a dualidade esperada. Em "Tristes Trópicos", publicado em 1955, aparecem os dados das expedições juntados como se fosse uma só expedição. Fez um croqui da divisão dual da aldeia Quejara, com cerca de 150 pessoas que foi reproduzida com detalhes para a localização das casas (LÉVI-STRAUSS, 2006, p. 206). Não há indicação de visita à aldeia Pobori e Jarudori que também estavam no rio Vermelho.

Espaço Ameríndio, Porto Alegre, v. 8, n. 2, p. 168-204, jul./dez. 2014. 
referentes empíricos ou significados dos símbolos, mas nos padrões formais, na forma como os elementos simbólicos relacionam-se logicamente uns com os outros para formar um sistema total. Para LéviStrauss a cultura é um sistema simbólico ou uma configuração de sistemas simbólicos. Penso não ser importante chegar às estruturas profundas ou elementares das culturas humanas que seriam formais, fixas, duradouras e imutáveis como as ideias inatas de Platão ou os modelos linguísticos, pois o que me encanta são os eventos, as contradições da vida humana trabalhadas nos mitos em forma binária nas narrativas simbólicas. Quando ouvimos uma música, harmonizamos a complexidade de contrapontos relacionando um tema e suas variações. Mesmo nos sistemas duais de classificação como o totemismo, em forma harmônica, os nativos impõem ao natural a sua lógica cultural (DAMATTA, 1976).

A relação entre uma estrutura simbólica e seu referente é fundamentalmente lógica e a base de seu significado, uma coincidência de forma não-afetiva, não-histórica, não-funcional que o pensamento selvagem congela e dá racionalidade e a antropologia, como a música e a matemática, pode apreender e revelar. E essa racionalidade possui categorias lógicas e relações construídas a partir da consciência humana para perceber o mundo em termos de discriminações e oposições binárias.

Para Lévi-Strauss os sistemas culturais são também formais e, porque criados pelos humanos culturalmente inseridos, podem ser apreendidos também pela mente humana. As relações de oposições binárias subjazem a todos os aspectos de uma cultura e podem ser encontrados em todas as culturas. Estes axiomas básicos não só refletiriam como também testemunhariam as atividades universais da mente humana. E a teoria de Lévi-Strauss pode, em certo sentido, seria uma reafirmação de que a humanidade inteira exibe uma unidade psíquica fundamental.

Este modo paradoxalmente superficial de olhar as metades cerimoniais sem "concretude" nas relações sociais das etnias envolvidas não se confirma no futuro, pois as metades possuem dimensões que talvez não puderam ser percebidas num primeiro momento, contudo direcionam as ações das etnias em estudo. 
ALOIR PACINI - Em tempo de Copa do Mundo, os jogos dos povos indígenas em Cuiabá

Otto Zerries (1976) traz uma tabela Antinomias na imagem do mundo e na organização dual do índio brasileiro na qual indica as etnias marcadas pela dualidade: os Fulniôs, Xukurus, Kamakáns, Kaingangs, Akuens (Xerente e Xavante) Canelas, Apinajés, Kayapós, Suyás, Bororos, Tapirapés, Tembés, Mundurukus, Parintintins, Tupi-Kawahivas, Kepikirivát, Kaxinawás, Tukunas, Palikurs, Terenas, Yaruros (Venezuela), Jicaques, Kogis, Canaris (Equador), Incas, Quechuas, Aymaras e UruChipayas. Roberto DaMatta (1976) encontrara entre os Apinajés esta organização que valoriza as metades e a pensou para outros campos da sociedade brasileira como a casa e a rua, o privado e o público... E eu acrescento os Rikbaktsa e os Chiquitanos com os quais pesquiso e percebo fortes traços de dualidade, contudo, aspectos destas dualidades podem ser encontrados em todas as etnias.

Marcos Terena conta que em 1996 foi realizada a primeira edição dos Jogos dos Povos indígenas em Goiânia, na época do Ministro Pelé, Edson Arantes do Nascimento (FERREIRA, 2010, p. 22). Desde então, no intervalo entre os Jogos Nacionais, ocorrem Jogos estaduais que, organizados pelo ITC, são eventos que seguem o mesmo padrão de estrutura social, política, cultural e econômica (articulação com instituições parceiras, definição de modalidades esportivas, local de realização, divulgação, etc.).

Participei dos I Jogos Interculturais Indígenas de Mato Grosso, de 27 a 30 de junho de 2007, que reuniu cerca de 400 atletas (FERREIRA, 2010 , p. 22) ${ }^{9}$ de diversas etnias em Campo Novo dos Parecis ${ }^{10}$. As modalidades esportivas ali foram o hipipi (arco e flecha), o jikunahati

\footnotetext{
9 Para mais informações a respeito das diferentes edições dos Jogos ver Grando (no prelo), Ferreira (2010); Ferreira et al (2011) e Camargo (2007).

${ }^{10}$ Este município de Campo Novo dos Parecis fica distante 385 quilômetros da capital Cuiabá (segue-se pela BR-163 até Jangada e pela BR-364 até Tangará da Serra). Está no Médio-Norte do Estado de Mato Grosso, na região do Chapadão dos Parecis e tem uma vegetação de transição entre Amazônia e Cerrado, nas Terras Indígenas que ainda não foram tomadas pelas plantações de soja e algodão. Tendo a soja como carro-chefe, a base da economia no maior chapadão de terras agricultáveis do planeta é o agronegócio. Os principais rios são: Sucuruína, Sangue, Membeca, Verde, Sacre, Cravari e Papagaio, águas que se juntam ao Amazonas. Trinta por cento de seu território é ocupado por áreas indígenas pertencentes às aldeias Bacaval, Seringal, Bacaiuval, Sacre II e 4 Cachoeiras. No turismo, destacam-se o local sagrado de várias etnias conhecido como Ponte de Pedra, e as cachoeiras Salto Belo e Utiariti. Neste aspecto é sugerido um intercâmbio cultural com as comunidades indígenas locais. A região abriga cerca de dois mil Parecis, distribuídos por 49 aldeias, dois mil Nambikwaras, 379 Manokis, 102 Mykys (Cf. FUNASA, 2010) etc. A Terra Indígena Ponte de Pedra é o local ancestral, ou melhor, os mitos de origem das etnias citadas localizam nesta pedra sua origem. É a partir dali que foram se espalhando os humanos pelo planeta terra. Por isso, este local teria sido escolhido para representar as comunidades indígenas das Américas neste ritual da chama olímpica "Revezamento da Tocha Rio 2007".
}

Espaço Ameríndio, Porto Alegre, v. 8, n. 2, p. 168-204, jul./dez. 2014. 
ALOIR PACINI - Em tempo de Copa do Mundo, os jogos dos povos indígenas em Cuiabá

(futebol de cabeça), o arremesso de lança, a corrida de tora, a natação de rio, as lutas corporais e o futebol. A modalidade do futebol que envolveu os indígenas presentes não foi anunciada e nem divulgada, mas geralmente é muito apreciada pelos atletas indígenas. Somente com o tempo é que a comissão organizadora dos Jogos foi se convencendo e, por vezes ainda parece não convicta, de que não era o caso de criar dicotomias entre esportes de branco e esportes de índio e percebeu que poderia ser colocada oficialmente como uma das modalidades tradicionais indígenas.

Representando as comunidades indígenas das Américas, Campo Novo do Parecis (MT) participa, no próximo dia 27, do Revezamento da Tocha Rio 2007. Uma cerimônia espiritual, às margens do rio Sacre, na aldeia 4 Cachoeiras, abre a programação às 9 horas $e$ 48 minutos, com o Ritual de Celebração do Fogo Ancestral ${ }^{11}$ Indígena para Recepção à Tocha Rio 2007. A cenografia do local será a mais natural possível, onde serão montados, uma arena para as danças, um dispositivo para autoridades e Bandeira Nacional e a Pira Indígena que terá uma ilustração baseada na mitologia dos tupi-guarani, explicando o surgimento do nome Brasil.

O fogo, produzido com a tecnologia milenar de fricção da madeira, vai acender uma tocha indígena desenhada especialmente para o ritual. No final da tarde, o revezamento oficial da tocha pan-americana faz um percurso de quatro quilômetros pelas principais ruas do município e dá início aos I Jogos Interculturais Indígenas de Mato Grosso (PANTANAL PRESS, 2014, n.p.).

Esta conexão mística entre o local - área central da América do Sul onde teriam surgido os primeiros povos indígenas -, e o ponto de partida da tocha olímpica, nas pirâmides astecas de Teotihuacán, onde os Deuses teriam se tornado humanos, é que fez com que as etnias do

\footnotetext{
${ }^{11}$ As narrações relativas à obtenção do fogo são semelhantes no acervo mítico das mais diversas etnias espalhadas pelo continente. Entre os Guaranis, ela se dá pelo herói civilizador Nhanderequeí (SCHADEN, 1976, p. 306-314). Somente o sapo cururu conseguiu guardar uma brasa na língua quando Nhanderequeí se fez de morto e os urubus que voam nos altos céus fizeram uma fogueira para assá-lo. Nhanderequeí cuida do fogo seguindo com detalhes educativos os passos, mas os animais terrestres não querem mais o fogo por causa da fumaça e as aves por causa do cheiro de queimado. Transcendendo o caráter episódico, este mito espelha a maneira pela qual os diferentes grupos Guaranis Mbyás e Kayovás cuidam do fogo.
}

Espaço Ameríndio, Porto Alegre, v. 8, n. 2, p. 168-204, jul./dez. 2014. 
Planalto Central da América do Sul em Campo Novo dos Parecis participassem do revezamento na condução da chama olímpica, representando não um país específico, mas todas as nações e povos indígenas das Américas.

$\mathrm{Na}$ ocasião, sugeri aos representantes do Ministério dos Esportes que se apresentasse oficialmente o jikunahati como modalidade para as Olimpíadas, pois seria o que de mais original os povos indígenas poderiam oferecer, pois são mestres nesta modalidade. $O$ valor especial do jikunahatil2 que se encontra amplamente disseminado pelas etnias do Chapadão dos Parecis, pode ser articulado com outras formas de "futebol" que se jogava no império Asteca e Maya, cujas quadras ainda podem ser encontradas nos sítios arqueológicos deixados por estas tradições milenares. Também existem relatos de que etnias indígenas praticavam o jogo de bola com os pés na Amazônia colonial. Esta arte futebolística herdada dos ancestrais tem motivado torneios e disputas entre diferentes etnias indígenas e contra a população envolvente, intercâmbios necessários entre sociedades em disputa por terra e direitos sociais e culturais.

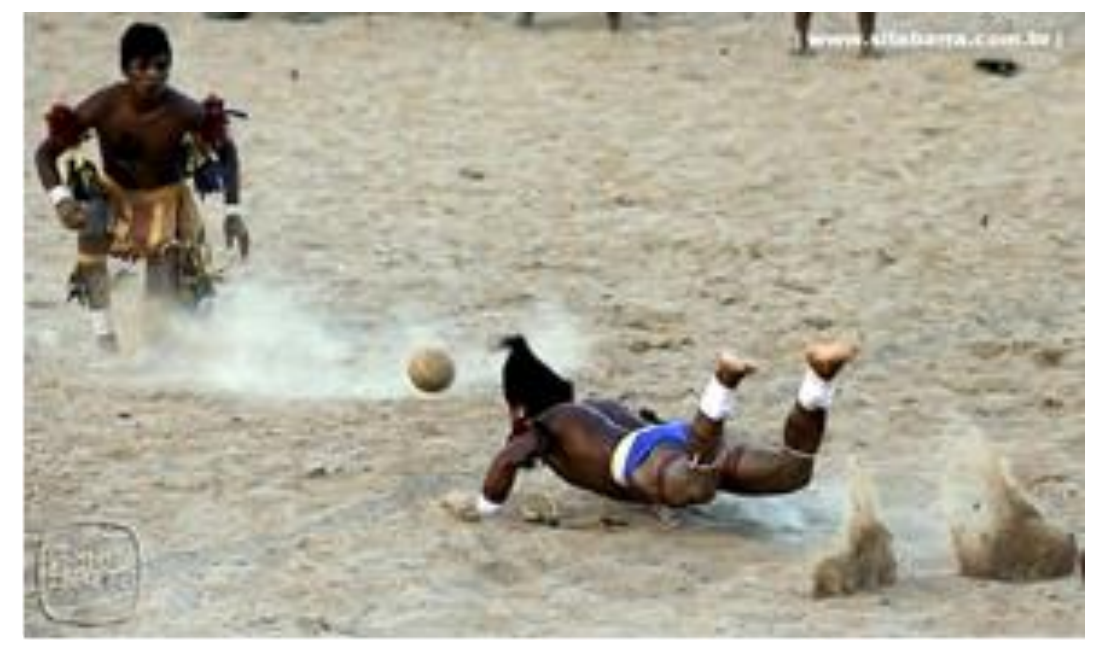

Imagem 3: Várias páginas da web incluem esta dinâmica do jogo de futebol de cabeça indígena.

12 O Xikunahity, também conhecido como futebol de cabeça ou cabeçabol, já foi muitas vezes etnografado: a bola é empurrada com a cabeça dos participantes e o jogo é disputado por equipes de cerca de dez atletas em um campo de dimensões próximas ao do futebol de salão.

Espaço Ameríndio, Porto Alegre, v. 8, n. 2, p. 168-204, jul./dez. 2014. 


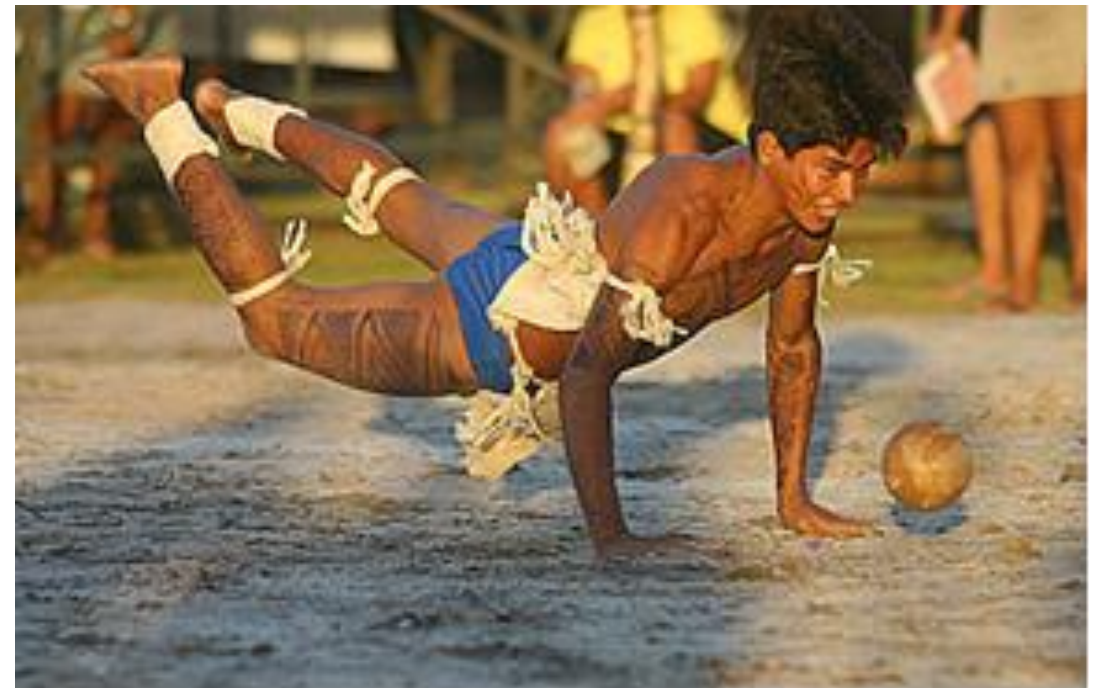

Imagem 4: Xikunahity, o futebol de cabeça (Foto de Roberta Tojal).

Importante destacar que durante esses eventos, ocorrem mesas de discussão sobre temas que interessam aos povos indígenas. Sobretudo nos eventos estaduais, analisar esses momentos de discussão é algo ainda a se fazer, pois são momentos em que a festividade cede lugar à tensão por, muitas vezes, apontar para questões locais em que os envolvidos, indígenas e não indígenas, estão presentes. Exemplo foi o fórum de discussões com o tema "Afirmação da Identidade Cultural Indígena como Valor Nacional", no qual participei como expositor durante os jogos de Mato Grosso que gerou tensões na Câmara de Vereadores, pois a discussão a respeito de direitos indígenas não era o que interessava no momento. Como também não é o foco deste artigo, por isso voltemos ao que interessa: as exposições fotográficas e de artes, pinturas corporais indígenas e apresentações culturais folclóricas que aconteceram na cidade, e o foco principal que foram os Jogos e, entre eles, o futebol.

Com o tema "Celebrando as Tradições dos Primeiros Povos", os jogos indígenas de Mato Grosso foram classificados como interétnicos. No critério de seleção das etnias que participaram deste evento foram avaliados aspectos tais como: o grau de preservação da língua, dos costumes e das manifestações culturais como cantos, danças mais ou menos inseridas em rituais com flautas ou não, pinturas corporais, além 
ALOIR PACINI - Em tempo de Copa do Mundo, os jogos dos povos indígenas em Cuiabá

dos artefatos e esportes tradicionais. Pois este evento tinha como objetivo despertar nos jovens indígenas o reconhecimento de seus valores e a interação entre as sociedades no Mato Grosso com uma argumentação clara: trata-se de um dos maiores "celeiros de diversidade cultural indígena do País e das Américas" (PORTAL DA EDUCAÇÃO FíSICA, 2014, n.p.). Talvez esta associação aos celeiros de grãos seja automática, mas penso que não menos intencional com a produção de soja nestes territórios tradicionais indígenas, pois estes são em geral tratados como mercadorias pelos poderes públicos. 0 Estado de Mato Grosso "tem" cerca de 40 mil índios em 42 etnias, entre elas, a etnia Pareci que participou do ritual de recepção da tocha panamericana e este é também um marketing a ser explorado.

\section{Uma herança cultural}

Carlos e Marcos Terena fizeram parte de um grupo de jovens indígenas que foram estudar em Brasília, com bolsas concedidas pela FUNAI. Lá formaram um time de futebol denominado União das Nações Indígenas - UNIND (SANT'ANA, 2010, p. 101). Alguns indicam a organização de uma seleção indígena entre Terenas, Bakairis, Karajás, Tuxás e Xavantes (VIANNA, 2008) para disputar uma partida de futebol contra o Centro de Ensino Unificado de Brasília (CEUB), no dia 19 de abril de 1979, como um marco histórico, pois, posteriormente, esta equipe indígena se apresentou em outros estádios brasileiros como o Maracanã. Em 1985, uma delegação indígena mais oficial disputou os XIV Jogos Escolares Brasileiros realizados na cidade de São Paulo. Os jogos esportivos e as competições em geral possuem funções culturais que podem ser observadas tradicionalmente entre os indígenas. $O$ jogo está presente em nossas vidas mesmo quando não nos damos conta e em formas muito variadas: desde duelos poéticos até insultos, tambores, provas de conhecimento, prontidão de espírito na demonstração de força e coragem, muitas vezes como preparação para a guerra. A noção de competição não é incentivada nos jogos indígenas, pois o slogan tem uma herança nas olimpíadas, porém parece ir além ou mesmo ficar aquém, não importa se o melhor está no início ou no fim, 
ALOIR PACINI - Em tempo de Copa do Mundo, os jogos dos povos indígenas em Cuiabá

pois o importante é celebrar13, talvez porque desejava-se que permanecessem intimamente ligados à religião. Amanda Teixeira, Diretora da UNE, entrou de carona nesta canoa dos Jogos com os universitários Karajá Xambioá da UFT ou "militantes, voluntários, pesquisadores e atletas da UFT", conforme noticiado, e expressou um dos anseios dos Jogos:

um grande momento de confraternização dos povos indígenas, o evento também é símbolo de resistência, fortalecimento político, manutenção e resgate de suas tradições, avivamento cultural e enfrentamento aos preconceitos (UNE, 2013, n.p.).

O zelo competitivo diz mais respeito aos jovens que precisam submeter-se a dolorosas experiências como iniciação à vida adulta. À primeira vista, o jogo poderia parecer distante em relação ao direito, à justiça e à jurisprudência, contudo, "o caráter sagrado e sério de uma ação de maneira alguma impede que nela se encontrem qualidades lúdicas" (HUIZINGA, 2007, p. 87). Por mais lúdico que seja um jogo ou, por mais dura que seja uma guerra, também esta é um jogo que segue regras: "A conclusão de tudo isto é que sem espírito lúdico a civilização é impossível. [...] No fundo, o problema é sempre ganhar - embora saibamos muito bem que esta forma de 'ganhar' não pode dar lucro" (HUIZINGA, 2007, p. 114).

Nas sociedades que melhor realizaram as promessas do capitalismo e do estilo de vida burguês, esse modo de existir fundado no indivíduo, no mercado e na ideia básica de propriedade privada, causa espanto 0 entusiasmo dos brasileiros pelas festividades ligadas ao corpo como o carnaval e, hoje em dia, a Copa do Mundo (DAMATTA, 2006, p. 91).

Mesmo assim vamos fazer Copa do Mundo, olimpíadas, jogos indígenas... e usamos os recursos públicos que deveriam estar direcionados na educação e saúde, reivindicação legítima dos movimentos sociais em junho de 2013, na construção de estádios de futebol e outros. Alguns mais lúcidos afirmam que os recursos que estão sendo investidos nos estádios e centros de treinamentos, no VLT,

13 “O Importante não é ganhar, sim celebrar!", talvez sem celebrar.

Espaço Ameríndio, Porto Alegre, v. 8, n. 2, p. 168-204, jul./dez. 2014. 
ALOIR PACINI - Em tempo de Copa do Mundo, os jogos dos povos indígenas em Cuiabá

não iriam nunca para a saúde e a educação. São recursos que apareceram quando firmados o compromisso com a FIFA e o sinal dos ingressos todos vendidos para a Copa mostram isso. O fato de ser exótico o lugar entre Pantanal, Cerrado e Floresta Amazônica fez com que não fosse estranho que Cuiabá estivesse entre as sedes escolhidas para alguns jogos da Copa de Futebol em 2014.

Na história, na arte e na literatura, tudo aquilo que vemos sob a forma de um belo e nobre jogo começou por ser um jogo sagrado. Os torneios e justas, as ordens, os votos, os títulos, são todos vestígios dos ritos de iniciação primitivos (HUIZINGA, 2007, p. 117).

O zelo pelas apresentações esteticamente bem representadas sob formas de pinturas corporais é um jogo que contribui para a eficácia desses ritos cheios de arte em forma de culto do corpo.

Perderam-se os elos explícitos com este passado longínquo fincado na religião, mas ficamos nós aqui no centro da América do Sul com estes "jogos" de diferentes modalidades para compreender o que está acontecendo na nossa sociedade!

Toda metáfora é um jogo de palavras e o espírito humano salta entre a matéria e as coisas pensadas. Enquanto as formas mais complexas da vida social indígena como a religião, o direito, a guerra e a política estão conectadas com este jogo14, talvez "um jogo de espelhos", parafraseando o grande Lévi-Strauss, pois o mito é sempre jogo sagrado e esta poesia se articula com o rito na forma de sua expressão na Antropologia:

A reciprocidade das perspectivas que se impõe ao pensamento mítico para tornar possível a constituição dos três universos em um sistema fechado faz com que cada um ofereça a sua própria imagem e reflita a dos dois outros. Esse jogo de espelhos explica que no mundo de cima uma humanidade gigante esteja em relação aos humanos como os humanos em relação aos anões; e que, no mundo de baixo, uma fauna arborícola gigante, também um requisito ideal, esteja

\footnotetext{
${ }^{14}$ Não estamos buscando "as regras do jogo social” (LÉVI-STRAUSS, 2006, p. 128), mas compreender o que se passou nestes dias em que os indígenas interagiram intensamente com a sociedade brasileira em geral, mas também particularmente entre eles, mostrando-se nas suas diversas formas de serem indígenas atualmente no Brasil.
}

Espaço Ameríndio, Porto Alegre, v. 8, n. 2, p. 168-204, jul./dez. 2014. 
ALOIR PACINI - Em tempo de Copa do Mundo, os jogos dos povos indígenas em Cuiabá

em relação aos humanos como eles em relação à fauna arborícola real (LÉVI-STRAUSS, 1986, p. 146).

Ou seja, aqui estamos trabalhando várias perspectivas para compreender fenômenos sociais como o jogo de futebol sem pretensões de esgotamento do assunto, mas simplesmente com o objetivo de colocar em discussão questões que nos envolvem no cotidiano e fazem com que se movam grandes parcelas da população brasileira. Não somos somente objetos passivos neste processo e uma discussão maior talvez nos dê condições de compreender melhor o que está acontecendo conosco na cidade de Cuiabá e Várzea Grande.

A partir da revisão dos trabalhos de Wissler, Kroeber, Steward e Murdock, a consciência da temporalidade limitada e a artificialidade das construções nas contribuições de Galvão para as regiões culturais levou a apresentações de regiões específicas das áreas culturais indígenas do Brasil mais fundamentadas em dados etnográficos revistos e produzidos entre os anos de 1900 e 1959. Contudo, os sinais diacríticos de regiões geográficas não deixavam de ser caricaturas da realidade a ser apresentada para o exterior (SILVA, 2007).

Por isso, Julio Cezar Melatti (1976) propôs a superação das dificuldades teóricas dessa construção artificial abandonando a divisão em áreas culturais e a substituindo pela identificação de pólos de articulação indígena, inspirado em estudos sobre a hierarquia que as cidades exercem sobre o rural e, neste campo, os indígenas. O esforço em cartografar as sociedades indígenas relacionadas às cidades pólos (sedes dos municípios aos quais estavam submetidos e que lhes estão próximas como se fossem pontos), e unir esses pontos por linhas de espessuras diversas conforme o número de relações que os ligassem como intercasamentos, trocas comerciais, convites para rituais, procura dos serviços de médicos-feiticeiros, procura de hospitais, participação em eleições, procura de escolas, apresentações culturais em eventos como o dia do índio e outros tantos aspectos que poderiam ser citados foi um passo para afastar a perspectiva da uniformidade e a homogeneização cultural em favor de uma maior atenção nas relações sociais. Esse esforço de identificar os laços das sociedades indígenas entre si e com as parcelas da sociedade nacional como um todo permitia observar cada qual como uma totalidade sócio-cultural e dava um 
retrato da relação de submissão destas sociedades indígenas aos impulsos da sociedade brasileira. Não estranhamos que Cuiabá queira mostrar-se solidária aos povos indígenas quando no Mato Grosso acontece um avanço violento do agronegócio sobre os territórios tradicionais indígenas e campanhas acirradas contra a demarcação destes territórios para o usufruto dos indígenas, haja vista o filme Manoel Chiquitano Brasileiro que denuncia a situação desta etnia na fronteira. Esta etnia foi deliberadamente espurgada dos Jogos... Chegaram mendigando espaço para participarem ao menos nas apresentações culturais, mas foram despachados sem ter voz e vez nesta organização que não desejava sua visibilidade neste meio preparado para inglês ver.

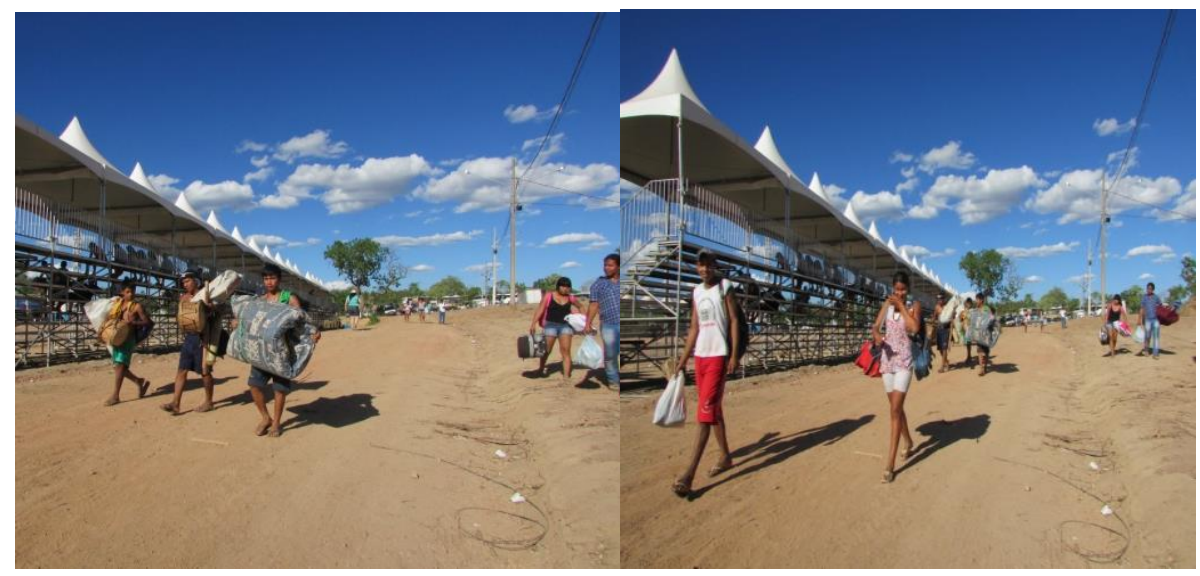

Imagens 5 e 6: Chegada dos Chiquitanos com malas, colchões e instrumentos musicais (caixas, flautas e pífanos) no final da tarde do dia 9. Sem espaço e sem voz foram de volta para suas aldeias indignados com a discriminação sofrida porque não possuem uma Terra Indígena demarcada no Mato Grosso.

Segundo o Comitê Intertribal que define as etnias nos Jogos Indígenas, a escolha considera regionalismos das origens étnicas com base no mapa geográfico indígena:

A liderança indígena ressalta que, entre os critérios adotados para a escolha das delegações, o fator cultural foi determinante. 'Pensamos em costumes, práticas e origens de suas falas, linguagem, ritos, danças, cantos, instrumentos musicais, artesanatos, pinturas corporais e principalmente seus esportes 
ALOIR PACINI - Em tempo de Copa do Mundo, os jogos dos povos indígenas em Cuiabá

tradicionais', informa, ao destacar que o número de etnias convidadas a participar dos jogos será fechado de acordo com os recursos orçamentários programados. [...] Com relação à escolha das representações de índios brasileiros, Terena esclarece que a busca é feita de comum acordo com as autoridades indígenas, ou seja, um rodízio entre aldeias e etnias (BRASIL, 2013, n.p.).

Parece-me claro que os não-indígenas não queriam ver os Chiquitanos no local dos Jogos porque ali se joga com o exótico e esta etnia é fortemente questionada na sua indianidade pelos fazendeiros e políticos no Mato Grosso. Não houve sensibilidade dos organizadores para compreender esta problemática local ou mesmo forças suficientes para enfrentar o agronegócio em vista da demarcação de suas terras, pois trata-se de um elemento político muito forte se houvesse o reconhecimento dos demais indígenas do país. Por isso os Chiquitanos não tiveram espaço nos Jogos.

Penso também que não houve esforços para agrupar e articular os indígenas, mas mostrou-se as diferenças de cada sociedade indígena como uma redoma ou um momento desconectado de suas lutas pela sobrevivência neste mundo capitalista. Apesar das muitas partilhas que não puderam ser etnografadas e aconteceram apesar do ambiente não ser benéfico a estes espaços de lutas políticas, pareceu a este observador que este momento comum dos Jogos mostrou mais sua vida cultural e social "em pedaços".

Após o café da manhã, as diferentes etnias se locomoviam de um lugar a outro com auxilio dos ônibus cedidos pela organização, os mesmos ônibus com que vieram da aldeia à cidade de Cuiabá para as competições de futebol masculino e feminino que ocorriam paralelamente em diferentes pontos da cidade. O estudante de Etnologia Indígena do Curso de Ciências Sociais, Danilo Rodrigues que acompanhou os Boes (Bororos) como atachê, também chamado "tradutor" ou acompanhante dos indígenas neste evento, observou que mulheres de algumas etnias não puderam competir quando culturalmente estas e crianças não podem separar-se de seus maridos. No caso Boe (Bororo), ambos não puderam participar na "torcida" durante as competições, e caracterizava o evento como turístico, pois 
competiriam no mesmo dia, local e hora. O atachê captou questões interessantes que mostraram ser o futebol a competição mais relevante no cenário da vida social das aldeias, pois o campo de futebol ocupa espaço central das mesmas, geralmente ao lado de espaços sagrados como a casa dos homens e outros espaços cerimoniais, a única competição a ocorrer fora da estrutura da arena dos jogos e das poucas competições "não-indígenas" na programação dos jogos. Contudo, ouviu de seus interlocutores que essa edição só contemplaria jogos/competições tradicionais indígenas. E impressiona os dados que, quando cogitaram a não realização do futebol voltaram atrás, pois diziam que se não houvesse futebol "ninguém iria participar" "ninguém iria vir para os jogos", "nenhuma etnia viria". Observou que as mulheres Boes (Bororos) perderam no futebol e para algumas os jogos já "havia acabado", ou "não me importo mais, depois que perdemos no futebol". E mais impressionante ainda foi que, depois da disputa do cabo-deguerra em que foram campeãs houve a manifestação clara pelo valor da competição: "Eu não me importo, não me senti vitoriosa, porque nós empatamos e para ganhar alguém deve perder. Mas para mim os jogos acabaram quando perdemos no futebol. Eu queria muito ganhar no futebol" (J.R. 19 anos)15. E quando retornavam à Aldeia Okara, comemoravam um jogo ganho. No futebol masculino os Canelas foram os vencedores.

Encontrei publicado por Ana Lúcia Cruz Os povos indígenas e a paixão pelo futebol (2014) um breve comentário que corresponde às minhas intuições: "A paixão dos índios brasileiros pelo futebol não se explica apenas pela influência da cultura não indígena sobre os primeiros habitantes do país". E o futebol acaba sendo uma modalidade de destaque nos Jogos dos Povos Indígenas. E os times de futebol feminino têm grande popularidade nas disputas. Neste ano de 2013, as campeãs foram as índias Gavião Parkateje, da cidade de Marabá do Pará que enfrentaram as Kura-Bakariri do Mato Grosso. Um único comentário feito no mesmo site sobre "Time feminino do Pará é campeão dos jogos indígenas de 2013" feito por Gustavo Ferreira em 15 de dezembro de 2013 às 2:31 mostra uma torcida: "Bacana ver que o Gavião Kyikatejê

\footnotetext{
${ }^{15}$ Entrevista concedida a Danilo Rodrigues.
} 
ALOIR PACINI - Em tempo de Copa do Mundo, os jogos dos povos indígenas em Cuiabá

vai estar na elite do Parazão 2014, representando Marabá, que tem time até na Série C (Águia). Vai que eles surpreendem!".

\section{Uma inserção pontual da UFMT nos Jogos Indígenas}

O Ministério do Esporte quis ampliar as instituições parceiras para planejamento também no conhecimento científico, contudo, 2013 se tornou "o pior acolhimento aos 48 povos, com 1600 indígenas, de todos os tempos" (GRANDO, no prelo, p. 19).

A Escola Difusionista (Kulturkreislehre), influenciada por Ratzel16, enfatizava a limitada capacidade de invenção do ser humano e o papel das migrações e difusão cultural na evolução social. Essa escola tentou definir um número limitado de círculos culturais, ou centros de dispersão, nos quais teria surgido a maioria de nossas inovações sociais e culturais. Boas (2011)17, um dos principais teóricos na antropologia norte americana, foi enfático ao afirmar que o ambiente geográfico não é "o único determinante" a atuar sobre a mente supostamente idêntica de todas as "raças da humanidade", pois assim deveríamos concluir que um mesmo meio produzirá os mesmos resultados culturais em toda parte. Constatamos que povos que vivem num mesmo ambiente mostram muitas diferenças e a antropologia chega cada vez mais à conclusão de que as condições geográficas não têm o poder de modificar a cultura, pois o ambiente sempre atua em uma cultura preexistente e não sobre um hipotético grupo sem cultura. Se algum ideal de origem única de todas as formas de cultura sempre adquirida por empréstimo persiste, de certo modo, reafirma o evolucionismo execrado pela antropolgia.

\footnotetext{
${ }^{16}$ Ratzel concebia o ambiente, em vez da invenção particular ou do esforço do indivíduo por exemplo, como a causa principal da diversidade e da distribuição das culturas. Para ele a sociedade respondia à natureza do mesmo modo que um animal a seu meio.

${ }^{17}$ Boas ressaltou a possibilidade da multi-determinação considerando não só pelo contato entre os povos (os fatores externos), mas também pela dinâmica própria dos fatores culturais, as pressões dos ecossistemas e características bio-psicológicas dos humanos (os fatores internos da dinâmica cultural) apreendidas pelos estudiosos da antropologia cultural através dos diversos métodos dessa ciência: a análise comparativa do tipo físico, pesquisa arqueológica, estudos e semelhanças na língua e na cultura seguida pela delimitação geográfica (cf. BOAS, 1899). Ruth Benedict (1887-1948), aluna de Franz Boas, teórica dos padrões culturais (1934), observa que os traços que se agrupam geograficamente, devem ser manejados "geograficamente" e não antropologicamente. Aqui, porém, estou procurando compreender simplesmente a influência dos jogos indígenas no Brasil atual.
}

Espaço Ameríndio, Porto Alegre, v. 8, n. 2, p. 168-204, jul./dez. 2014. 
ALOIR PACINI - Em tempo de Copa do Mundo, os jogos dos povos indígenas em Cuiabá

A UFMT também entrou como parceira neste processo e estive numa reunião para alguns encaminhamentos, o que me deixou preocupado com os resultados deste envolvimento. Os irmãos Carlos e Marcos Terena são tidos como os "idealizadores" dos Jogos e possuem certa tradição na elaboração destas atividades com as articulações políticas que Ihes são próprias enquanto estratégias próprias de sua etnia nos diálogos com o mundo que os cerca. Carlos Terena é dito articulador cultural da ONG ITC (Comitê Intertribal Memória e Ciência Indígena) ${ }^{18}$, que cria convênios com as Prefeituras, no caso Campo Novo dos Parecis e Cuiabá, o Governo de Mato Grosso e o Ministério do Esporte para viabilizar estes eventos mencionados e outros. O dramático é que as delegações indígenas de diferentes etnias são "convidadas" por Marcos e Carlos Terena e, com isso, fazem a sua política de domínio sem nenhum exercício democrático.

Distante e de difícil acesso, o local escolhido para os Jogos decepcionaram inicialmente, pois o público não comparecia aos espetáculos ${ }^{19}$. Por isso novas estratégias de divulgação tiveram que ser montadas nos jornais impressos e televisivos 20.

A Programação XII Jogos dos Povos Indígenas, ditos também "Jogos Verdes", não dão a dimensão do que foi o evento em termos de riqueza de acontecimentos que auxiliam a pensar. As duas turmas da UFMT (Serviço Social e Ciências Sociais) foram liberadas nas minhas aulas para acompanhar os acontecimentos e trouxeram para a reflexão dados importantes que se refletem neste escrito.

A Aldeia Okara na Região Sucuri recebeu no final de tarde do dia 8, a Cerimônia de Acendimento do Fogo Ancestral Indígena. Este ritual

\footnotetext{
18 Marcos Terena com outras lideranças nacionais, tais como Eliane Potiguara, o Itiarrori Karajá, o Aritana e outros criaram a associação multiétnica Comitê Intertribal (ITC) na ECO92 na qual Marcos Terena foi presidente por muitos anos. Esta associação é uma das decorrentes dos movimentos sociais, políticos, de direito e vontades dos indígenas (Sant'Ana, 2010, p. 112). Organizado pelo Comitê Intertribal - Memória e Ciência Indígena (ITC), desde 1996, os Jogos dos Povos Indígenas conta com atividades esportivas específicas como canoagem, arco e flecha, cabo de força, arremesso de lança, corrida de 100 metros, de tora e natação. O Governo repassa os recursos do Ministério do Esporte ao ITC, para que atue como gestor dos recursos e da adaptação do local para sediar os jogos.

19 Ver vídeos publicados em 09/11/2013 sobre a Abertura dos Jogos Indígenas em Cuiabá (https://www.youtube.com/watch?v=TQCzDoUswsA) e $12^{\circ}$ edição dos Jogos Indígenas 2013 Cuiabá/MT (https://www.youtube.com/watch?v=xbnnU3dT-0M).

${ }^{20}$ Em 12/11/2013, João Guilherme Barros postou suas Imagens e Edição dos jogos gravados no dia 10/11/2013: "Nesse vídeo mostro a feira de artesanato indígena, tiro com zarabatana, as provas de corrida feminina com toras, tiro com arco e flecha e dança" (BARROS, 2013, n.p.).
}

Espaço Ameríndio, Porto Alegre, v. 8, n. 2, p. 168-204, jul./dez. 2014. 
para acender o fogo sagrado com o atrito de gravetos realizado ao por do sol representa a união entre os povos.

Somente no dia seguinte foi a Abertura Oficial, uma composição de elementos culturais ancestrais para contemplar os políticos. No dia 10/11/13 (Domingo) teve entretenimentos culturais: Feira de alimentos indígenas, exposição, vendas de artesanatos, pinturas corporais e literaturas na Aldeia Okara. No final de tarde os Jogos Nativos de Integração: $1^{\text {a }}$ Eliminatória: Arco e Flecha. As demonstrações dos jogos tradicionais sempre são interessantes: Kaipy, Zarabatana, Hiara, Jawary, Rõnkran, Huka Huka e Corridas de Tora Feminino/Masculino.

Todas as noites deveriam acontecer apresentações culturais dos indígenas e do folclore regional, mas estes foram raros. Destaque desta noite foi Cunhã Porã: As belas indígenas. No dia seguinte continuaram os Jogos Nativos de Integração: $1^{\text {a }}$ Eliminatórias: Arremesso de Lança/ Cabo de Força Masculino e Corrida de 100 metros feminino. Os Jogos Tradicionais Demonstração: Xaka-akere, Kagót, Peikrãn, Akô, Takpipi, Yamurikumã (lutas), Uiwede Wapraba e Jikunahati. No dia 12/11/13 (Terça-feira), os Jogos Nativos de Integração: $1^{\text {a }}$ Eliminatória: Corrida

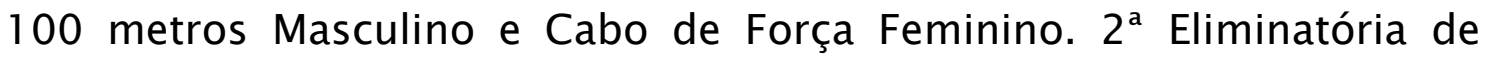
Arco e Flecha; e Jogos Tradicionais Demonstração: Tihimore, Kagót, Wakmeti, Idjassú, Anjâly, Katukaywa e Peikrãn. 
ALOIR PACINI - Em tempo de Copa do Mundo, os jogos dos povos indígenas em Cuiabá

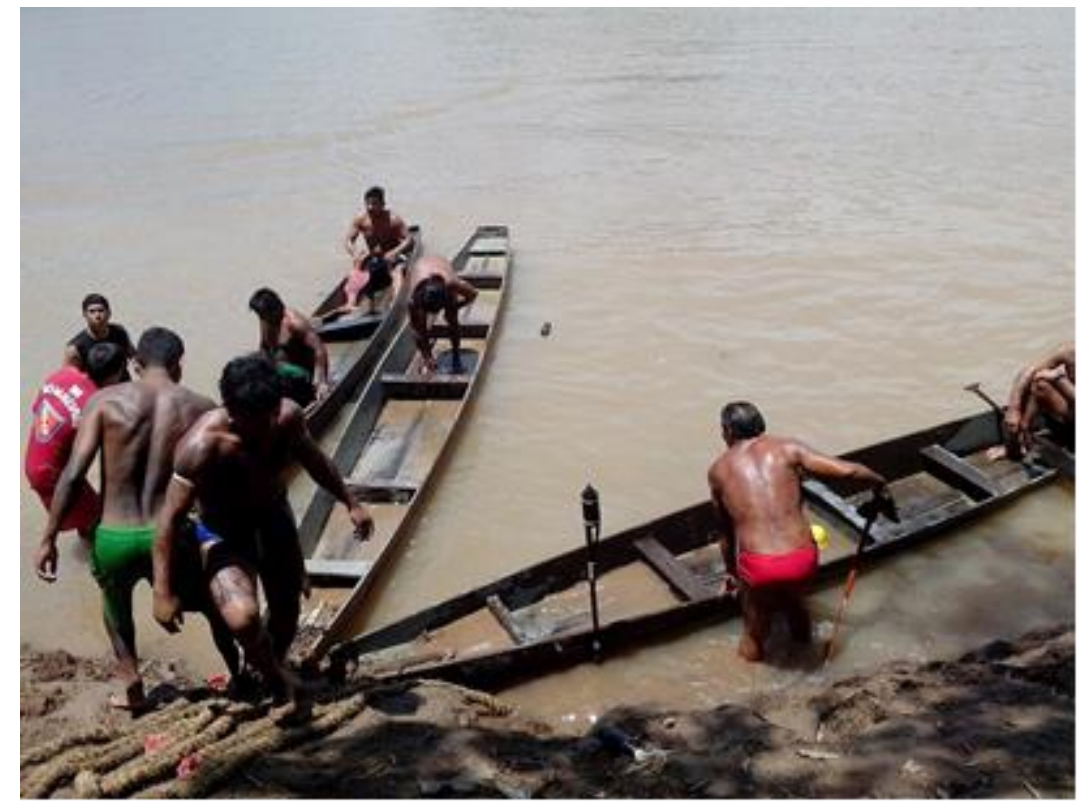

Imagem 7: O contato no rio Cuiabá já poluído se deu na canoagem com as canoas fabricadas pelos Rikbaktsa por serem consideradas navegáveis por todas as etnias, nos banhos e ao lavar roupa (foto de Andhressa Heloíza Sawaris Barboza em 15/11/2013).

A causa da diarreia que acometeu alguns num primeiro momento parecia estar relacionado com as más condições de higiene da Aldeia Okara que alagava na chuva, com a água poluída do rio Cuiabá onde muitos foram se banhar e lavar a roupa e também com os bebedouros de água que não davam conta de deixá-la fresca para o consumo. Também ocorreu diarreia durante a Rio +20 no Rio de Janeiro. Penso que um conjunto de fatores estão envolvidos como o tipo de comida, o ar poluído, água com cloro, a distância do ambiente de aldeia etc. A estas explicações dadas pelos próprios indígenas, acrescente-se a feitiçaria e a tensão com para apresentarem-se bem nos jogos e, por que não dizer, vencer as competições. Por causa dos muitos problemas de saúde enfrentados pelos indígenas devido à insalubridade dos locais de alojamento na Aldeia Okara, fomos convocados para uma pesquisa. Acompanhei como antropólogo a vistoria dos locais para entrevistas da equipe de saúde, e havia muita água acumulada no pátio das casas do alojamento e algumas etnias já haviam abandonado o local em $15 / 11 / 13$ (Sexta-feira). 
ALOIR PACINI - Em tempo de Copa do Mundo, os jogos dos povos indígenas em Cuiabá

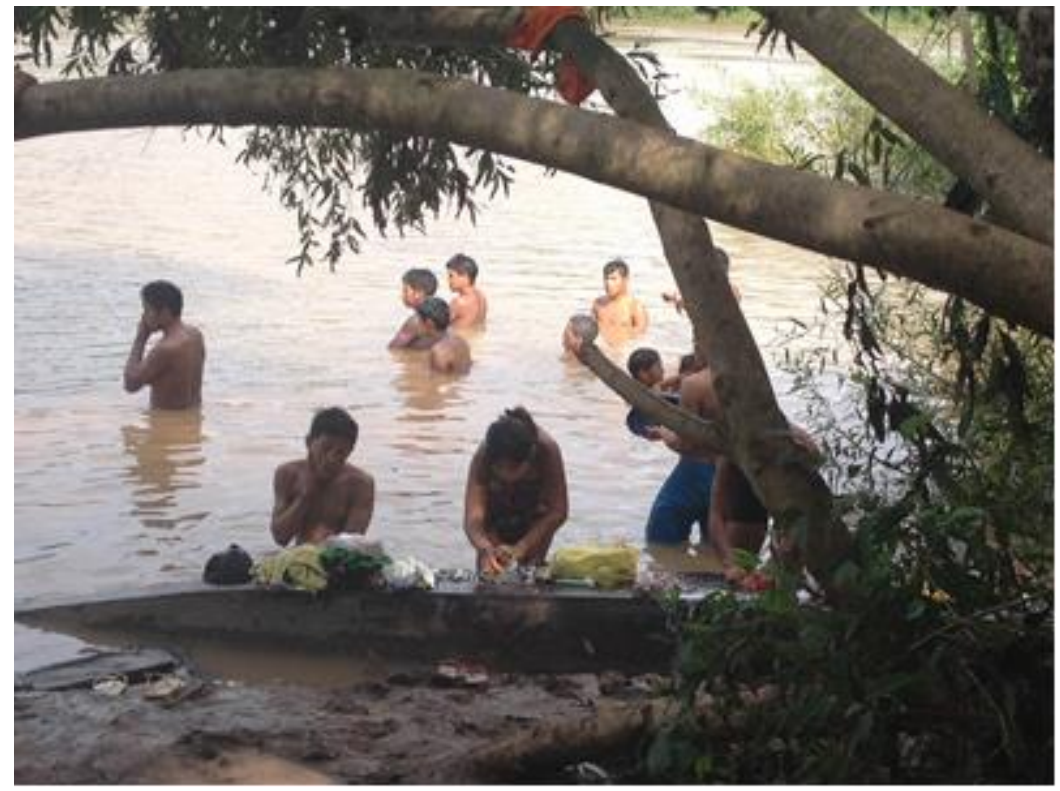

Imagem 8: Índios durante banho e lavando roupas no rio Cuiabá. Fonte: Igor Moura Danieleviz e Silva ${ }^{21}$.

No trabalho de saúde entrevistamos os Karajás com casos de diarreia: Kuirá (20-08-1968) e Isaque Waxio. Passamos na oca dos Rikbaktsa e entrevistamos os enfermos e na oca dos Suruis Paiter não havia ninguém, estava abandonada. Entrevistamos também Bergro Kayapó (7-7-1995) do município de Kumaru (PA) e Bepydji Kayapó informou como ficou doente com diarreia.

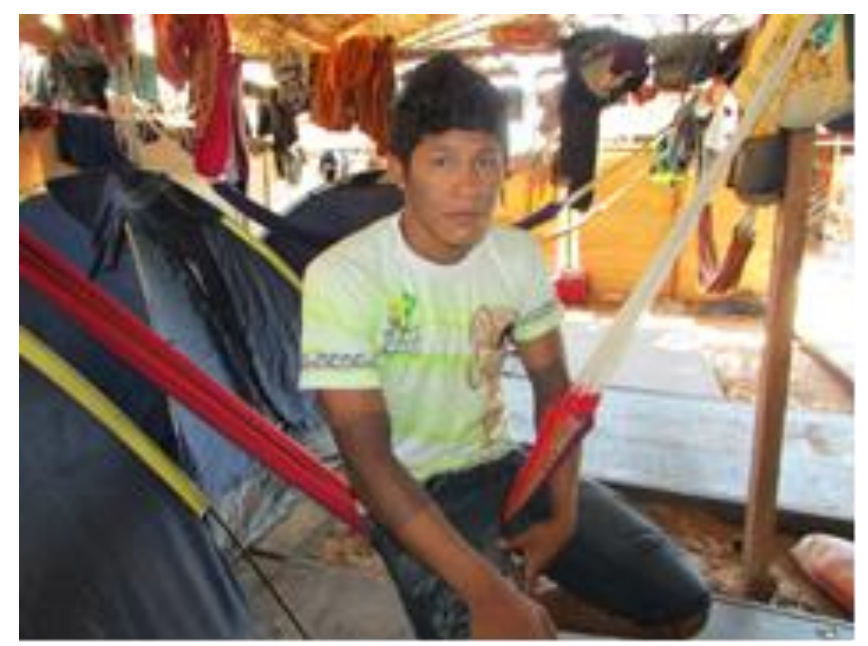

Imagem 9: Alojamento dos Kayapós visitados para coleta de informações a respeito de surto de diarreia e outras doenças. Foto do autor, 16/11/13.

21 Discente do curso de Ciências Sociais da Universidade Federal de Mato Grosso. E-mail: igor.mourad@yahoo.com.br.

Espaço Ameríndio, Porto Alegre, v. 8, n. 2, p. 168-204, jul./dez. 2014. 
ALOIR PACINI - Em tempo de Copa do Mundo, os jogos dos povos indígenas em Cuiabá

Os Jogos Nativos de Integração como a corrida de tora masculino e feminino e o arremesso de lança eram os mais apreciados pelo público externo. Só que começavam em geral depois do horário previsto. Os Jogos Tradicionais Demonstração: zarabatana, rõnkran, jawari, kaipy, haindu, katukaywa, takpipi, tumutitekré e huka huka (masculino e feminino) também arrancavam do público muitos aplausos.

$\mathrm{Na}$ quinta-feira aconteceram os Jogos Nativos de Integração $\left(2^{\mathrm{a}}\right.$ Eliminatória de cabo de força masculino e feminino) misturados com os Jogos Tradicionais Demonstração (kaypi, jawary, peikrãn, corrida de tora e idjassú), o que mostrou ser bastante artificial esta distinção. No dia 15/11/13 (Sexta-feira) era feriado e o público cresceu vertiginosamente. Pela manhã não houve mais futebol e aconteceram os esportes aquáticos: natação e canoagem no rio Cuiabá. À tarde os Jogos Nativos de Integração: final de corrida de tora masculino e feminino e corrida de 100 metros feminino e masculino. Os Jogos Tradicionais Demonstração: xaka-akere, wa'í, zarabatana, tumutitekré, kagót. No Sábado pela manhã houve a corrida de fundo masculino e feminino no Jardim Botânico. De tardinha aconteceram as finais dos Jogos Nativos de Integração: arremesso de lança, arco e flecha, cabo de força masculino e feminino na Arena Central da aldeia montada especialmente para este evento. Algumas atividades ficaram para o Domingo e no final de tarde estávamos ali despedindo-nos de algumas equipes, como dos Rikbaktsa22, Boes (Bororos) e Terenas.

Observei que só haviam tendas dos artefatos para: Umutinas e Krahos23; Tupinambás; Xavantes; Wassu-cocal e Xocós; Macuxis e Waiwais; Terenas e Guaranis Kaiowás; Zorós e Sateré-Maués; Kayapós; Kayabis e Matipus; Embrapa. Os demais tinham que vender suas coisas expondo-as no chão ou em cima de mesas num pavilhão que ficava super-lotado, principalmente quando chovia.

\footnotetext{
${ }^{22}$ Recordo que nos idos 1989 e 1990, quando fiquei morando entre os Rikbaktsa, fiquei impressionado que eles se dividiam entre torcedores dos times de São Paulo e Rio de Janeiro e logo soube por que: a Rádio Nacional da Amazônia transmitia estes jogos e este era o único meio de comunicação ao qual tinham acesso na época.

${ }^{23}$ Os Krahos habitam o norte do Estado de Goiás e estão incluídos entre os Timbiras que falam uma língua da família Jê. A maneira de transmitir os nomes pessoais entre os Krahos e o complexo cosmológico que mantém sobre a procriação expressam uma dualidade que transmitem a todos os seres, algo semelhante aos Kaingangues e outras etnias.
}

Espaço Ameríndio, Porto Alegre, v. 8, n. 2, p. 168-204, jul./dez. 2014. 
ALOIR PACINI - Em tempo de Copa do Mundo, os jogos dos povos indígenas em Cuiabá

Segundo José Ronaldo Fassheber (2006), o kanjire é um jogo de guerra que foi desaparecendo das práticas corporais Kaingangues e, em seu lugar, aparecia o futebol, a mimesis que adquire um lugar central nas relações de re-inserção sociais nas Terras Indígenas (TIs) Kaingangues e com a sociedade envolvente. Tanto entre os Kaingangues como entre os Xavantes, Boes, Chiquitanos e outros, os campos de futebol se localizam no centro das aldeias e a comunidade se reúne para jogar e assistir às "peladas"; as equipes Kaingangues disputam competições contra equipes de vilas e cidades da região, uma integração com os brancos que não pode ter o teor de afirmação da identidade étnica entre os Chiquitanos, pois ofereci um jogo de uniformes ao time da Vila Nova Barbecho, com a condição que aparecesse o nome Chiquitano, por isso dispensaram a oferta.

$\mathrm{Na}$ lista dos esportes que poderiam ser classificados como nãoindígenas, porém aviso que eu os considero indígenas também porque o praticam nas aldeias ${ }^{24}$, está apenas o futebol masculino e feminino. Para Cuiabá estava anunciado que, além das atividades esportivas, o evento teria a realização de feiras de artesanato dos povos, de produtos agrícolas e da literatura indígena, assim como apresentações culturais e debates políticos. E, durante os Jogos, os 16 países participantes realizariam também um Fórum Social Indígena, onde seria discutida, dentre outras pautas, a realização do I Jogos Mundiais Indígenas, previsto para ocorrer em 2015 e ter o Brasil como país sede.

Apesar da mudança recente que se impõe progressivamente em relação ao futebol exclusivamente masculino, crasce a participação das mulheres, não deixa de nos fazer pensar o jogo como um ato sexual que chega ao orgasmo em cada gol: "Quando a bola entra no gol, ela se transfigura e adquire uma consistência metonímica: por ela, enquanto encarnação de um trabalho conjunto, é a equipe toda que penetra no espaço de segredo. Um gol é uma orgia" (AGUIAR, 1987, p. 158). Por isso é necessário rearticular-se depois do gol sofrido e recompor-se depois do gol feito porque o jogo continua. Sem replays ou câmara lenta

\footnotetext{
${ }^{24}$ As posturas puritanas em relação aos costumes indígenas estão sendo superadas aos poucos pelo trabalho dedicado dos antropólogos que sabem que a cultura é dinâmica e modifica no tempo e não criam problemas com as incorporações de costumes alienígenas por causa dos contatos e mestiçagem e misturas próprias da realidade na qual vivemos.
}

Espaço Ameríndio, Porto Alegre, v. 8, n. 2, p. 168-204, jul./dez. 2014. 
ALOIR PACINI - Em tempo de Copa do Mundo, os jogos dos povos indígenas em Cuiabá

para apreciar melhor cada gol ou vitória nos jogos indígenas, foi preciso viver o presente absolutamente.

Não importa se é metáfora de ato sexual ou de guerra. No cabo de guerra não existe quem vença os Enawenenawes que na euforia da vitória final receberam o microfone para comemorar e celebrar, mas o que ouvimos foi a palavra firme indígena: "Governo tem que demarcar a Terra Indígena Enawenenawe Adoinã (Rio Preto)!"25. E assim o som do microfone foi cortado, a voz indígena mais uma vez lhes foi tirada, pois este não é um assunto bem quisto nestes espaços e nestes tempos.

\section{E a Copa do Mundo em Cuiabá...}

Considero pertinente aqui o conceito de futebol como mediador cultural utilizado na pesquisa do prof. Francisco Xavier Freire Rodrigues (Esporte e Diversidade Cultural em Mato Grosso: um estudo sobre o futebol entre os índios Umutina). O momento das manifestações no Brasil foi especialmente simbólico do paradoxo que é o Brasil com baixa distribuição de renda e demandas da população reprimidas no campo da saúde e educação. Em Cuiabá tivemos a maior manifestação contra a corrupção e a Copa no dia 21/06/2013, e os tapumes apareciam com indicações de que o cidadão cuiabano não era tatu, pois a cidade se tornara um canteiro das 56 obras em andamento sem terminar nenhuma. A menor sede entre as 12 do Mundial recebeu cerca de 100 mil turistas. O Instituto Vetor considerou que $91,6 \%$ dos visitantes aprovaram Cuiabá e recomendariam Mato Grosso como destino turístico. $67 \%$ da população local aprovou a Copa e a média nacional de aprovação da Copa foi de 63\% (conforme Datafolha). Serviram como ameaça, se vocês não nos ouvir "Não vai ter Copa", mas também quebrou o consenso no Brasil de que todos somos aficionados pelo futebol e que a Copa e as Olimpíadas iriam ser bom para todos. Ficou mais clara a privatização dos lucros para a FIFA e a socialização dos prejuízos (PAULA e BARTELT, 2014): as elites foram assistir aos jogos nas Arenas e chegaram até a vaiar a presidente Dilma gerando mal-

\footnotetext{
${ }^{25}$ Esta Terra Indígena fica junto ao Rio Preto, um afluente das cabeceiras do rio Juruena, norte do Mato Grosso, onde tradicionalmente pescavam.
}

Espaço Ameríndio, Porto Alegre, v. 8, n. 2, p. 168-204, jul./dez. 2014. 
estar geral26 e os pobres ficaram nos fanfests ou em suas casas assistindo os jogos na TV.

É escandaloso em Cuiabá que a Arena Pantanal fosse construído derrubando o Estádio Verdão e agora se torna obsoleto, sem condições de se manter, mais escandaloso ainda é que essa e outras obras fossem superfaturadas para gerar lucros para uns poucos, num processo de corrupção que está enraizado na sociedade brasileira, e isso não é só o caso dos políticos. Por isso faltam recursos para os direitos básicos do cidadão à saúde e educação, mas os indígenas continuam sendo apontados como os vilões da falta de progresso no Brasil. Os indígenas são o único segmento da população brasileira que perdeu no governo Dilma, mesmo assim os fazendeiros e políticos do Mato Grosso que isso queriam, como Blairo Maggi e Riva que manifestamente tem se posicionado contra a demarcação do território tradicional dos Chiquitanos, não passaram a apoiar Dilma, ou seja, são alianças que não geram dividendos para o PT.

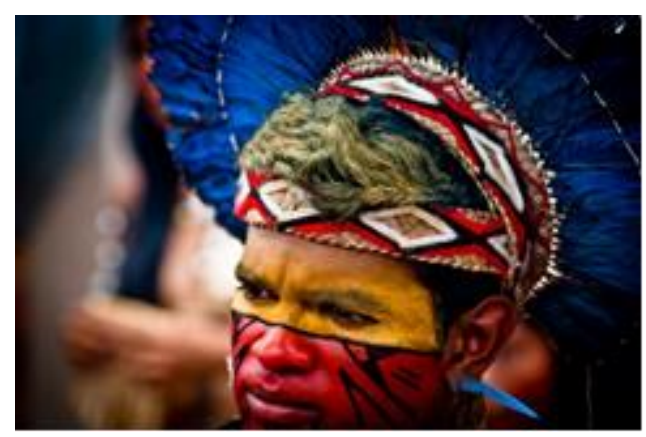

\footnotetext{
${ }^{26}$ Algumas pessoas mais críticas observaram que esta vaia foi organizada pelo PSDB que deseja a presidência do Brasil no próximo pleito, por isso o que gerou um mal-estar está para além do resultado dos jogos na Copa de 2014. Por isso continua pertinente a pergunta: Como o mal-estar se exprimirá depois da copa?, na entrevista ao filósofo Rodrigo Nunes (2014).
}

Espaço Ameríndio, Porto Alegre, v. 8, n. 2, p. 168-204, jul./dez. 2014. 
ALOIR PACINI - Em tempo de Copa do Mundo, os jogos dos povos indígenas em Cuiabá
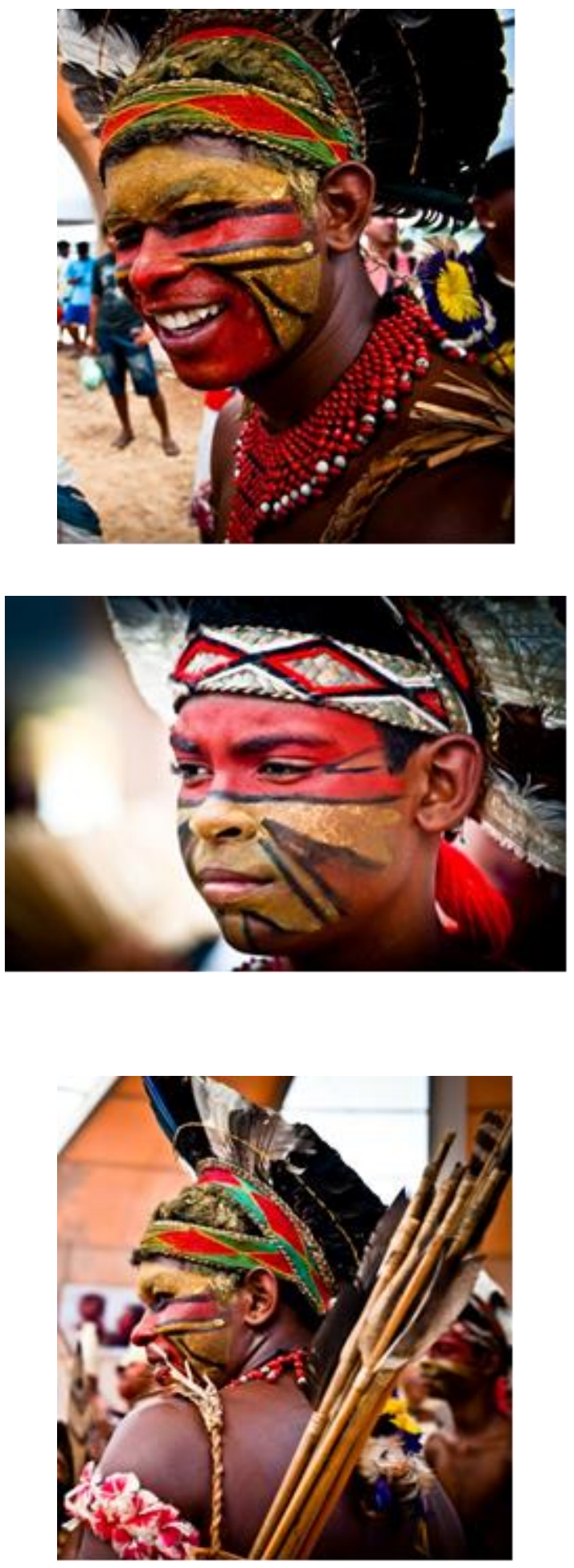

Espaço Ameríndio, Porto Alegre, v. 8, n. 2, p. 168-204, jul./dez. 2014. 


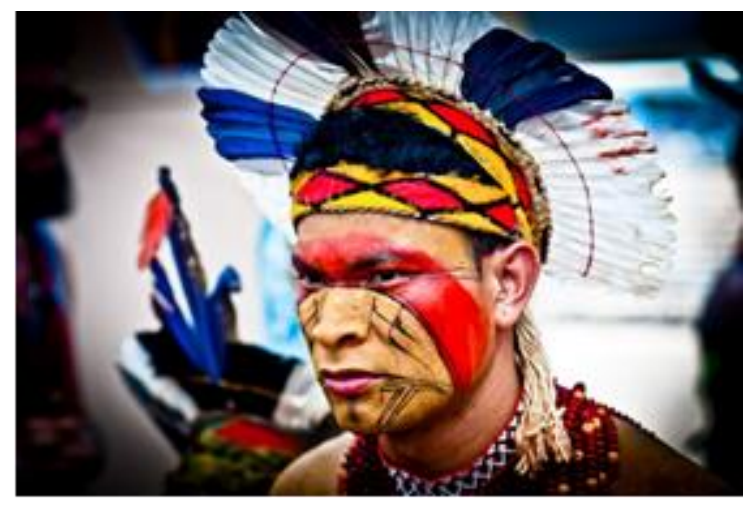

Imagens 10 a 14: Fotos dos Pataxós disponibilizadas nos sites do Governo de Mato Grosso com os mesmos padrões estéticos das pinturas masculinas com as três cores da bandeira da Alemanha: RFP 3048; RFP 3043; RFP 3059; RFP 3078; RFP 3037;

http://www.mt.gov.br/imagens/?keyword=jogos+indigenas $+2013 \& \mathrm{x}=39 \& \mathrm{y}=13 \mathrm{e}$ https://www.flickr.com/search/?q=jogos+indigenas+2013.

No futebol tivemos que mostrar o nosso gingado e certa liberdade nas formas de jogar para ganhar algumas Copas. Com essas vitórias associadas à herança indígena na dualidade dos times e no modo de pensar que está tudo bom ou tudo ruim, as massas no Brasil se identificaram com o futebol, pois os jogos se ganham ou se perdem. Em geral os meninos pobres sonham com os salários astronômicos dos jogadores e se iludem largamente porque as estatísticas mostram que uma ínfima minoria chega a ser profissional. Contudo, o complexo de vira-latas - que também as elites brasileiras trazem consigo - também foi quebrado agora com a capacidade de sediar uma Copa em alto estilo. O mesmo Instituto Vetor observou em Cuiabá que muitos estavam com vergonha e medo em sediar a Copa (42\%). Depois dos jogos, $72,5 \%$ disseram que Cuiabá não teve motivos para se envergonhar, 55,2\% dos turistas elogiaram a hospitalidade cuiabana. Os cartões Visa tiveram um aumento de $963 \%$ de movimento se comparado com o período do ano de 2013. O que mais deu certo foi a acolhida do povo brasileiro e a visibilidade da "alegria" dos brasileiros foi altamente elogiada pelos estrangeiros. A Copa de 2006 na Alemanha também aconteceu no clima festivo do verão, regado com cerveja e muita participação popular. Contudo, a infraestrutura (os estádios) já tinham sido construídos e o governo não precisou investir tanto como o governo do Brasil para ter um padrão de bem-estar para os turistas. 
No Jornal Nacional da Globo (20 horas do dia 10/07/201427) uma entrevista com os Pataxós da Bahia que ganharam dinheiro para comprar uma ambulância e a manutenção de uma escola até a próxima Copa do Mundo da Seleção de Futebol da Alemanha que se mostrou a mais simpática das seleções, foi mostrado algo da interação destes com a população local e um adolescente pintado tradicionalmente com o amarelo da argila, o vermelho do urucum e o preto do jenipapo e carvão, coincidentemente as cores da bandeira da Alemanha, o time que deu de 7 a 1 no Brasil no dia do "apagão inexplicável". O certo é que houve uma identificação simbólica entre estas equipes, talvez por isso, ainda em campo, a seleção alemã fez uma dança Pataxó em torno da taça tão almejada por todos e um jogador foi capaz de dar o prêmio da vitória para as crianças desta etnia. As notícias mostraram que até a Alemanha ficou surpresa, pois haviam estudado onde cada jogador do Brasil chutaria, no caso de pênaltis no final do jogo.

As frustrações são oportunidades para refletir a respeito das ilusões que a mídia imprime na população. Ninguém queria ver o planejamento estratégico e a dedicação dos outros times que superaram o Brasil nos jogos. E ficou o exemplo da campeã Alemanha para a posteridade: necessitamos de planejamento a longo prazo para investir no conjunto dos jogadores e não confiar em habilidades pessoais somente.

\section{Concluindo}

A escolha dos locais dos Jogos Indígenas e da Copa do Mundo possui interesses econômicos e relações com o povo do local que joga com o exótico, por isso talvez a definição das etnias que jogam segue mais o critério do que os não-indígenas querem ver do que é oficialmente dito. Contudo, o futebol deslocado da estrutura principal dificulta a participação das mulheres indígenas que não podem se distanciar de seus maridos e filhos, etc.

O fato de ser exótico o lugar entre Pantanal, Cerrado e Floresta Amazônica fez com que Cuiabá fosse escolhido também para sede de

\footnotetext{
${ }^{27}$ Cf. Folha (2014).
}

Espaço Ameríndio, Porto Alegre, v. 8, n. 2, p. 168-204, jul./dez. 2014. 
jogos da Copa de Futebol em 2014. O caráter político em geral abafado aparece quando os Enawenenawes falam sobre a demarcação de suas terras, por isso foi cortado o microfone que lhes dava voz e vez na vitória do cabo de guerra.

Parece ser esta a causa pela qual os Chiquitanos não tiveram espaço nos Jogos, apesar de ser esta uma forma adequada de reconhecimento dos demais indígenas do país para com estes indígenas no Mato Grosso que ainda não possuem nenhum pedaço de seu território tradicional demarcado para eles. Parece ser esta também a forma como o Estado do Mato Grosso quer chamar a atenção para o centro-oeste, esta região de grande produção agrícola para a exportação.

A articulação entre UFMT e a preparação Escolas mostra algumas necessidades para que dê certo um evento como este dos Jogos Indígenas. Contribuímos com a participação qualificada de alunos e professores das escolas públicas no estudo da temática indígena antecipadamente. A proposta foi a formação de professores garantida pela UFMT em parceria com a SEDUC-MT/CEFAPROCuiabá e a SMECuiabá, a fim de que fosse desenvolvido no período de setembro a novembro um projeto pedagógico nas escolas de Cuiabá, Várzea Grande e Poconé com a temática da história e cultura dos povos indígenas que estariam participando dos Jogos de Cuiabá. Os professores contaram com subsídios didáticos e diálogos com indígenas que atuam na educação escolar de Mato Grosso para a implementação da Lei $11.645 / 08$, que torna obrigatório o ensino das histórias e culturas dos povos indígenas do Brasil, em todos os níveis de ensino.

Este foi um grande diferencial neste evento, pois
embora nos demais as escolas eram levadas para
participar dos JPIN, os mesmos iam ter no evento um
primeiro contato com esta população ficando entre o
encantamento e o estranhamento do exótico (GRANDO,
no prelo, p. 23).

As dualidades podem entrar em equilíbrio, superar as rivalidades e se complementarem, porém isso se dá em tensão, pois vimos que a perspectiva do celebrar acima do vencer ainda é mais um ideal do que conquista e os Jogos estão em movimento. Tanto o cabo de guerra 
ALOIR PACINI - Em tempo de Copa do Mundo, os jogos dos povos indígenas em Cuiabá

como a corrida de torra, o futebol e outros são jogos que envolvem dois times, ou seja, possuem uma dualidade que envolve intensamente os indígenas. O que desejo colocar aqui é que os indígenas brasileiros estão na origem deste grande apreço que o Brasil tem pelo futebol, ou seja, a etnografia das atividades esportivas atuais nas aldeias, as experiências dos Jogos Indígenas e a etnologia tem mostrado justamente que estes povos já tinham o futebol de cabeça tradicional que envolve o próprio modo dos brasileiros jogarem o futebol de forma mais leve, com certo "gingado", se assim se pode dizer, e uma leveza que os levam a brincar em vez de competir.

E as torcidas dos times são também consequência desta dualidade que está enraizada neste modo de ser tão radicalmente gremista ou colorado - desculpem o regionalismo de minha origem gaúcha - tão marcada pelos Kaingangues que ocupavam tradicionalmente desde o rio Tietê (SP) até o rio Uruguai (RS).

A modalidade de esporte conhecida entre nós como o futebol ${ }^{28} \mathrm{se}$ tornou moda nacional por causa dos incentivos governamentais que desejavam uma identidade nacional - contudo não parece ser só isso, pois outros incentivos não vingaram no Brasil - e os indígenas participam deste incentivo na identidade nacional desde os Jogos Indígenas até os rituais nas aldeias que permitem quase a cada final de tarde uma "pelada", ou seja, um jogo de futebol, geralmente no centro da aldeia, principalmente quando estas são circulares como no caso dos grupos de tradição Jê. Contudo, além deste argumento, por onde tenho andado, os indígenas encontram um local para um campo de futebol, mesmo na aldeia Vila Nova Barbecho que possui somente 25 hectares para sobreviver segundo seus usos e costumes.

O futebol é espetáculo e mercadoria, feito para render lucros às elites: a bola rola, os dribles acontecem em meio aos meneios de corpo e chega-se ao gol. Os megaeventos esportivos garantem riqueza e poder aos jogadores e aos clubes vencedores. Os dirigentes políticos do Brasil institucionalizaram o futebol a partir de 1941 definindo que confederações e federações poderiam existir num jogo do poder e nos

\footnotetext{
${ }^{28}$ Também o carnaval foi incentivado pelo governo no tempo da República e vingou porque possui sua raiz indígena, contudo este não é o foco deste texto. Em outras áreas como o incentivo à produção industrial, a redução do esbanjamento ou um esforço organizativo e ético nos gastos governamentais e outros aspectos não têm tido resultados satisfatórios no Brasil.
}

Espaço Ameríndio, Porto Alegre, v. 8, n. 2, p. 168-204, jul./dez. 2014. 
anos 1950, o Brasil se associa às Olimpíadas e à Copa do Mundo, sempre submetidos à lógica do esporte/espetáculo/mercadoria, pois ironicamente, até os melhores jogadores entram na roda da "escravidão" e são comprados e vendidos em um sistema capitalista que oprime e exclui. E, em 1996, os indígenas também entraram nessa ideologia dos jogos. Por isso é lógico o grito "não vai ter Copa", pois o dinheiro público é capaz de destruir um estádio só porque tem financiamento para construir um novo e dar lucro a alguns. As mortes de operários e as remoções forçadas de milhares de famílias, tudo feito sem diálogo, o que impede a festa do povo, pois somente poucos podem pagar os preços exorbitantes dos ingressos e os pobres nem poderão comer as migalhas desse banquete dos ricos. Observo que se avisa que, se os vendedores ambulantes forem pegos vendendo coisas nas proximidades dos estádios, seriam presos. Assim os jogos estão marcados por protestos, violências e críticas. Nos dias da Copa ficamos sem aulas na UFMT que sabiamente colocou ali as férias para todos terem a oportunidade de serem livres. Contudo, o país parou por um mês e pouco para gerar lucros para a FIFA.

Vimos que a luta pela demarcação dos territórios tradicionais se mostrou inesperadamente na fala dos Enawenenawes e a manutenção das práticas culturais tradicionais que encantam nestes Jogos acabam sendo compreendidas pelos que participam em eventos desta natureza. Por isso penso que valem estas formas indígenas de dizerem a que vieram, mesmo que timidamente.

A cidade de Palmas foi escolhida pelo Ministério do Esporte e o Comitê Intertribal Memória e Ciência Indígena (ITC) como sede da edição mundial dos Jogos dos Povos Indígenas no segundo semestre de 2015 e tem uma expectativa de participação entre 22 e 30 países. Vivem atualmente no Tocantins cerca de 13 mil indígenas.

\section{Referências bibliográficas}

AGUIAR, Flávio. Notas sobre o futebol como situação dramática. In: BOSI, Alfredo 
ALOIR PACINI - Em tempo de Copa do Mundo, os jogos dos povos indígenas em Cuiabá

(Org.). Cultura Brasileira: Temas e situações. São Paulo: Ática. 1987. p. 151-166.

ALMEIDA, Arthur José Medeiros de. Esporte e cultura: esportivização de práticas corporais nos jogos dos povos indígenas. Brasília: Ideal, 2011.

BARROS, João Guilherme. Imagens e edição. 2013. Disponível em: https://www.youtube.com/watch?v=QijA93EY_8w . Acesso em: 09 mai. 2014.

BENEDICT, Ruth. Patterns of Culture. New York: Houghton Mifflin, 1934.

BOAS, Franz. The Jesup North Pacific Exedition. New York: Smithsonian Librarie, 1899.

A mente do ser humano primitivo. Petrópolis, RJ, Vozes, 2010.

BRASIL. Constituição da República Federativa do Brasil de 1988. Disponível em: http://www.planalto.gov.br/ccivil_03/constituicao/constituicao.htm . Acesso em: 21 abr. 2014.

Comitê intertribal define nomes de etnias nacionais. Brasília: Ministério do Esporte, 2013. Disponível em: http://www.brasil.gov.br/esporte/2013/10/comiteintertribal-define-nomes-de-etnias-nacionais . Acesso em: 24 dez. 2014.

CAMARGO, Vera Regina Toledo. Depoimento de Carlos J. Terena nos Jogos Interculturais Indígenas de Campo Novo do Parecis. Campinas: TV-UNICAMP, 2007.

CRUZ, Ana Lúcia. Os povos indígenas e a paixão pelo futebol, 2014. Disponível em: http://artilheiras.wordpress.com/category/tecendo-a-rede/. Acesso em: 09 mai. 2014.

DAMATTA, Roberto. Um mundo dividido: a estrutura social dos índios apinayé. Petrópolis: Vozes, 1976.

A bola corre mais que os homens: duas copas, treze crônicas e três ensaios sobre futebol. Rio de Janeiro: Rocco, 2006.

DURKHEIM, Émile. Le Dualisme de la Nature Humaine et ses Conditions Sociales. Scientia, v. 15, p. 206-221, 1914.

FASSHEBER, José Ronaldo Mendonça. Etno-desporto indígena: contribuições da antropologia social a partir da experiência entre os Kaingang. 2006. 172 f. Tese (Doutorado em Educação Física) - UNICAMP, [2006].

FERNANDES, Florestan. A função social da guerra na sociedade Tupinambá. São Paulo: Pioneira/EDUSP, 1970.

FERREIRA, Maria Beatriz Rocha. Jogos dos Povos Indígenas: diversidades. O Público e o Privado, Fortaleza, v. 8, n. 16, p. 65-80, 2010. 
ALOIR PACINI - Em tempo de Copa do Mundo, os jogos dos povos indígenas em Cuiabá

FERREIRA, Maria Beatriz R., CAMARGO, Vera Regina; VON SIMSON, Olga R. M. Jogo, celebração, memória e identidade: Reconstrução da Trajetória da Criação, Implementação e Divulgação dos Jogos Indígenas no Brasil (1996 - 2009). Campinas: Editora Curt Nimuendajú, 2011.

FIGUEIREDO, Karina. XII Jogos dos Povos Indígenas. Disponível em: https://www.youtube.com/watch?v=1Foaj9myCvQ . Acesso em: 09 mai. 2014.

FIORI, Justina. Jogos Indígenas: Cuiabá, a vitória do esporte. Revista Camalote, Cuiabá. v. 6, n. 64, p. 68-80, 2013.

FOLHA. Última entrevista da Alemanha na Bahia vira festa com índios e amuletos. Folha de São Paulo. 2014. Disponível em: http://www1.folha.uol.com.br/esporte/folhanacopa/2014/07/1484413-ultima-entrevistada-alemanha-na-ba-vira-festa-com-indios-e-amuleto.shtml . Acesso em: 24 dez. 2014.

FUNASA. Relatório de gestão 2010. 2010. Disponível em: http://www.funasa.gov.br/site/wp-content/uploads/2011/10/relatorio_2010.pdf. Acesso em: 24 dez. 2014.

GALVÃO, Eduardo. Índios do Brasil: áreas culturais e áreas de subsistência. Savador: UFBA, 1973 [1960].

GASPAR, Oscar Ramos. Com Crianças Indígenas, Banavita registra o futuro. Revista Camalote, Cuiabá, v. 6, n. 64, p. 62-66, 2013.

GRANDO, Beleni Saléte. Esporte e lazer indígena no Brasil: reflexões a partir dos jogos dos povos indígenas. (No prelo).

HAEKEL, Joseph. Zweiklassensystem, Männerhaus und Totemismus. Südamerika. Zeitschrift für Ethnologie, v. 70. 1938.

HUIZINGA, Johan. Homo Ludens: o jogo como elemento da cultura. São Paulo: Perspectiva. 2007.

LÉVI-STRAUSS, Claude. Contribution à l'étude de l'organisation sociale des Indians Bororo. Journ. Soc. Amér., Paris, v. 28, n. 2, 1936.

On Dual Organization in South America. América Indígena, v. IV, n. 1, 1944.

Tristes Trópicos. São Paulo: Companhia das Letras, 2006 [1955].

A Oleira Ciumenta. São Paulo: Editora Brasiliense, 1986.

MELATTI, Julio Cezar. Nominadores e Genitores: um aspecto do dualismo Krahó. In: SCHADEN, Egon. Leituras de Etnologia Brasileira. São Paulo: Companhia Editora Nacional, 1976. p.139-148. 
ALOIR PACINI - Em tempo de Copa do Mundo, os jogos dos povos indígenas em Cuiabá

MUNDURUKU, Daniel. Contos Indígenas Brasileiros. São Paulo: Global, 2005.

NUNES, Rodrigo. Como o mal-estar se exprimirá depois da copa?: entrevista. IHU, n. 446, p. 39-43, 2014.

PANTANAL PRESS. Jogos Indigenas em Mato Grosso. Cuiabá: Pantanal Press Assessoria de Imprensa. Disponível em: http://www.educacaofisica.com.br/index.php/component/content/article/142-coberturajornalismo/1295-jogos-indigenas-em-mato-grosso . Acesso em: 09 mai. 2014.

PAULA, Marilene de; BARTELT, Dawid Danilo (Org.). Copa para quem e para quê?: um olhar sobre os legados dos mundiais no Brasil, África do Sul e Alemanha. Fundação Herinrich Böll Brasil, 2014. Disponível em: http://bit.ly/1n1XoLJ (http://www.br.boell.org/). Acesso em: 24 dez. 2014.

PEREIRA, Levi Marques. Os Terena de Buriti: as formas organizacionais, territorialização da identidade étnica. Dourados: UFGD, 2009.

PORTAL BRASIL. Cuiabá recebe os jogos dos povos indígenas. 2013. Disponível em: http://www.brasil.gov.br/esporte/2013/10/cuiaba-recebe-os-jogos-dos-povosindigenas-2013/@@nitf_custom_galleria.Acesso em: 09 out. 2013.

PORTAL DA EDUCAÇÃO FÍSICA. Os jogos indígenas em mato grosso. 2014. Disponível

em: http://www.educacaofisica.com.br/index.php/component/content/article/142-coberturajornalismo/1295-jogos-indigenas-em-mato-grosso . Acesso em: 24 dez. 2014.

SANT'ANA, Graziella Reis de. Histórias, espaços, ações e símbolos das associações indígenas Terena. 2010. 331 f. Tese (Doutorado em Ciências Sociais) - Instituto de Filosofia e Ciências Humanas, Universidade Estadual de Campinas, [2010].

SCHADEN, Egon. A origem e a posse do fogo na mitologia guarani. In:

(Org.). Leituras de Etnologia Brasileira. São Paulo: Companhia Editora Nacional, 1976 [1955]. p. 306-314.

SILVA, Orlando Sampaio. Eduardo Galvão, índios e caboclos. São Paulo: Annablume, 2007.

STEWARD, Julien H. Culture Areas of the Tropical Forest. In: (Org.). Handbook of South American Indians: the Tropical Forest Tribes. Bureau of American ethnology, v. 143, n. 3, p. 883-899, 1948.

TERENA, Carlos J. O importante não é ganhar, mas celebrar. Revista de História da Biblioteca Nacional, Rio de Janeiro, v. 2, n. 22, p. 15-24, 2007.

UNE. Une participa dos XII jogos dos povos indígenas. 2013. Disponível em: www.une.org.br/.../une-participa-do-xii-jogos-dos-povos-indigenas . Acesso em: 24 
ALOIR PACINI - Em tempo de Copa do Mundo, os jogos dos povos indígenas em Cuiabá

dez. 2014.

VIANNA, Fernando. Boleiros do Cerrado: índios xavantes e o futebol. São Paulo: Annablume, 2008.

ZERRIES, Otto. Organização dual e imagem do mundo entre os índios brasileiros. In: SCHADEN, Egon (Org.). Leituras de Etnologia Brasileira. São Paulo: Companhia Editora Nacional, 1976. p. 87-126.

Espaço Ameríndio, Porto Alegre, v. 8, n. 2, p. 168-204, jul./dez. 2014. 